\title{
Magma water content of Pico Volcano (Azores Islands, Portugal): a clinopyroxene perspective
}

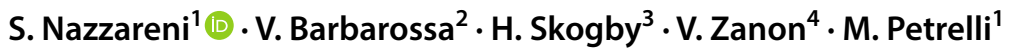

Received: 4 December 2019 / Accepted: 11 August 2020 / Published online: 28 August 2020

(c) The Author(s) 2020

\begin{abstract}
Clinopyroxenes from the Pico Volcano (Pico Island, Azores Archipelago) have been used as a proxy to define the water content of primitive magmas and the volcanological history of the erupted rocks. This very young volcano $(53 \pm 5 \mathrm{ka})$ is at a primordial stage of its evolution in comparison with the other volcanoes of the Azores. Clinopyroxenes from Pico Volcano underwent important dehydration processes and after annealing experiments under $\mathrm{H}_{2}$ gas flux, a pre-eruptive $\mathrm{H}_{2} \mathrm{O}$ content between 93 and $182 \mathrm{ppm}$ was recovered. A moderately high cooling rate for the cpx-host lavas expressed by the clinopyroxene closure temperature $\left(T_{\mathrm{c}}=755-928^{\circ} \mathrm{C} \pm 20^{\circ} \mathrm{C}\right)$ correlates with the dehydration, suggesting that this process may have occurred during magma ponding at the Moho Transition Zone (17.3-17.7 km) and/or after the eruption. By applying an ${ }^{\mathrm{IV}} \mathrm{Al}$-dependent partition coefficient to the measured $\mathrm{H}$ amount in clinopyroxene, the pre-eruptive water content of the parental magma was calculated to vary between 0.71 and 1.20 (average of 1.0) wt\%. Clinopyroxene geobarometry performed by combining X-ray diffraction with mineral chemistry points to a general crystallisation from the mantle lithosphere ( $\sim 8-9 \mathrm{kbar})$ to the oceanic mantle/crust boundary ( 4-5 kbar). The similar major and trace chemistry, water content and $\mathrm{Fe}^{3+} / \mathrm{Fe}_{\text {tot }} \mathrm{ratio}$ of clinopyroxene, suggest similar conditions of oxygen fugacity, water content and fractional crystallisation of the magma from which clinopyroxene cores crystallised during the Pico Volcano central eruptions from 40 ka to historical times.
\end{abstract}

Keywords Mantle $\cdot$ Intraplate magmatism $\cdot$ FTIR spectroscopy $\cdot$ Azores islands $\cdot$ Magma water content $\cdot$ OIB $\cdot$ Cpx geobarometry

Communicated by Gordon Moore.

Electronic supplementary material The online version of this article (https://doi.org/10.1007/s00410-020-01728-7) contains supplementary material, which is available to authorized users.

S. Nazzareni

sabrina.nazzareni@unipg.it

1 Department of Physics and Geology, University of Perugia, Perugia, Italy

2 Institute of Environmental Sciences, Leiden University, Leiden, The Netherlands

3 Department of Geological Sciences, Natural History Museum, Stockholm, Sweden

4 Instituto de Investigação Em Vulcanologia E Avaliação de Riscos, Universidade Dos Açores, Rua Mãe de Deus, 9501-801 Ponta Delgada, Portugal

\section{Introduction}

The Azores region is located at the triple junction between the North American, Eurasian and Nubian lithospheric plates, a complex region where a mantle plume intersects with the mid-Atlantic ridge (MAR) and is associated to the presence of the Terceira Rift, a slow-spreading oceanic rift system on a thick and relatively old lithosphere (Fig. 1). The Azores islands are well-known for their chemical heterogeneities both at regional and single island scale. At regional scale, heterogeneities have been for a long time ascribed to the interactions of a hot-spot-associated, deep-rooted mantle plume with the magmas ascending at the MAR (e.g. Schilling 1975; Cannat et al. 1999). However, this model has been questioned as a result of a number of geological observations, such as the lack of a coeval plateau and a time progressive chain of islands (Müller et al. 2008), by the lack of connection between the regional seismic anomalies ( 200-250 km deep) and the supposed deep source for 


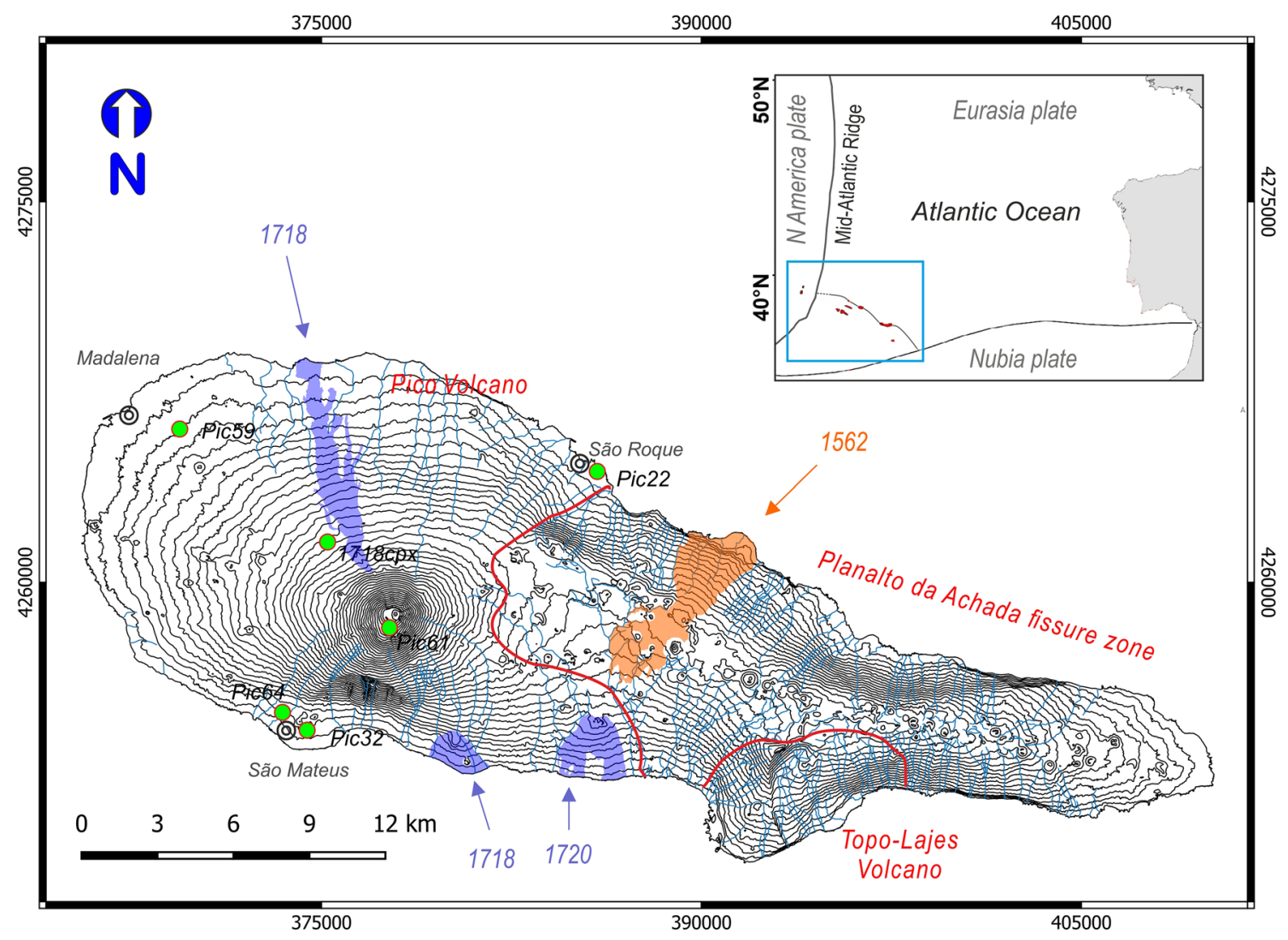

Fig. 1 Pico map. The three volcanic systems Pico Volcano, Planalto da Achada, and Topo-Lajes are reported. Historical eruptions (1562, 1718 and $1720 \mathrm{AD}$ ) and sample outcrops location are also reported

mantle plumes (Zhang and Tanimoto 1992; Courtillot et al. 2003; Montelli et al. 2004).

In the Azores region, a close association of different magmas coexist, namely the mid ocean ridge basalt (MORB) from the MAR and Ocean Island Basalt (OIB) from the Azores volcanoes. As a whole, the basalts emplaced along the MAR segments intersecting the Azores region are thought to be originated from dry $\left(50-200 \mathrm{ppm} \mathrm{H}_{2} \mathrm{O}\right)$ mantle source melting, whereas a wet (300-1000 $\mathrm{ppm}_{2} \mathrm{O}$ ) mantle source was initially postulated for the OIB magmas of the Azores (Hirschmann 2006). Geochemical data modelling indicated that the Azores magmas were produced by melting of a source with a minimum $\mathrm{H}_{2} \mathrm{O}$ content of $200 \mathrm{ppm}$ at temperature lower than that of a dry mantle (Asimow et al. 2004; Beier et al. 2012; Métrich et al. 2014). Nevertheless, few data are available on the water content of Azores magmas (Métrich et al. 2014; Turner et al. 2017), moreover, a detailed study on the pre-eruptive magma water content during the magmatic evolution of each single island is lacking.

Pico is the youngest among the Azores islands and developed by the overlapping of products erupted by three volcanic systems: Topo-Lajes to the South, Planalto da Achada fissure system to the East and Pico Volcano to the West
(Fig. 1). Topo-Lajes volcano (>186 ka) is eroded and partially collapsed (Costa et al. 2014). This edifice is partially buried by the lavas of the Planalto da Achada fissure system, a 30-km-long line of cinder cones which ultimately erupted in 1562. Pico Volcano is a steep conical edifice reaching $2351 \mathrm{~m}$ above sea level and is the youngest of the Azores (K/ Ar age of $53 \pm 5 \mathrm{ka}$; Costa et al. 2014), although its true base has never been dated. Recent eruptions occurred in 1718 and in 1720. This volcano differs from the other central volcanoes of the archipelago for the absence of a summit caldera (Nunes et al. 1999) even though the present summit is a wide crater showing evidence of instability.

The present work focuses on the pre-eruptive magma storage conditions of Pico Volcano with emphasis on the water content characterization, aiming at providing further constraints on the plumbing system, as well as to unravel the early evolution of the Azores volcanic systems.

The water content of magma is often determined by measuring the water content dissolved in glass and/or melt inclusions in olivine (i.e. Wallace 2005). However olivine may be scarce or absent in many volcanic rocks as well as it could not contain melt inclusions; then an alternative method, based on the analysis of hydrous species in 
nominally anhydrous minerals (NAMs), opened a new way to determine magmatic water contents. In fact, hydrogen can be found as a trace element in numerous NAMs, which can be thus used as a probe to estimate the activity of hydrous components especially in rock-forming silicates (see review of Keppler and Smyth 2006 and reference therein). Among NAMs, clinopyroxene is highly sensitive to variations of intensive parameters, like $P, T$ and $f \mathrm{O}_{2}$ and therefore, it was used to model geological processes (i.e. Dal Negro et al. 1989; Nazzareni et al 1998, 2001, 2020; Bindi et al. 1999; Perugini et al. 2003; Putirka et al. 2003; Putirka 2008). Moreover from the early studies on NAMs, pyroxenes were found to be able to host relatively high contents of hydrogen (e.g. Skogby 2006 and references therein). Because pyroxenes are really common in volcanic rocks they have been increasingly used to estimate the volatile budget of magmas (Wade et al. 2008; Nazzareni et al. 2011; Weis et al. 2015; Lloyd et al. 2016; Ferriss et al. 2016)

In a volcanic system, many different geochemical processes occur inside the magma reservoir, during the ascent, as well as after eruption. These processes may strongly affect the hydrogen content of NAMs, blurring its original value. Volcanological and petrological observations may help to constrain the possible $\mathrm{H}$ loss from NAMs. Another approach to estimate possible $\mathrm{H}$ loss is experimental rehydration under controlled conditions (e.g. Weis et al. 2015). We used this approach, by performing thermal annealing experiments under hydrogen gas flux, to evaluate the $\mathrm{H}$ lost by clinopyroxenes aiming to recover the pre-eruptive water content of the parental melt.

In detail, we selected basalts representing primitive compositions erupted by the lateral activity of Pico Volcano from less than $40 \mathrm{ka}$ to AD 1718 (Fig. 1) characterised by Zanon and Frezzotti (2013), Métrich et al. (2014) and Zanon et al. (2020). We measured hydrogen content, geobarometric data, and iron oxidation state at the core of clinopyroxenes extracted from the selected basalts to estimate the water content of the primitive parental melt in equilibrium with the clinopyroxene cores and reconstruct their crystallisation pressure.

\section{Data collection from literature}

Literature data have been collected from the Geochemistry of Rocks of the Oceans and Continents, GEOROC, database (https://georoc.mpch-mainz.gwdg.de). In detail, for whole rocks and clinopyroxenes, we downloaded the 'AZORES. csv' and 'CLINOPYROXENES.csv' files from the precompiled files by locations and minerals respectively.

\section{Pico rock geochemistry in the Azores framework}

Erupted magmas at the Azores islands belong to an alkaline series with $\mathrm{Na} / \mathrm{K}>1$, whose $\mathrm{SiO}_{2}$ content varies between $\sim 41$ and $\sim 68 \mathrm{wt} \%$ and the alkali content $\left(\mathrm{Na}_{2} \mathrm{O}+\mathrm{K}_{2} \mathrm{O}\right)$ ranges between $\sim 2$ and $\sim 14 \mathrm{wt} \%$ (Fig. 2). Mafic lavas (basalts, alkali basalts, hawaiites) and associated pyroclastic rocks forming cinder cones are by far more abundant than silicic rocks (trachytes, comendites, pantellerites). Mafic rocks are typical of the fissure zones present on each island and at the early stages of magmatism of central volcanoes, such as Pico Volcano; felsic rocks are erupted during plinian or sub-plinian eruptions, from vents located inside the summit calderas of the various stratovolcanoes or in forms of domes and coulees (Zanon 2015; Larrea et al. 2018). Intermediate terms (mugearites, benmoreites) are volumetrically insignificant, probably because of a rapid and effective process of mafic phases removal occurring in small reservoirs below central volcanoes. The geochemical evolution path of the magmas erupted is similar for all the islands, and fractional crystallization and/or crystal accumulation are the main processes that explain the Azores volcanic evolution starting from small pockets of magma (Zanon 2015; Larrea et al. 2018).

Pico Volcano is constituted by basalts (sensu lato) with reduced volumes of benmoreites erupted only during the AD 1718 eruption (Franca et al. 2006) (Fig. 2). Basalts were erupted by lateral fissures at lower altitudes and are frequently cumulitic due to a large amount of clinopyroxene and olivine. The rocks which constitute the summit cone are hawaiites and contain plagioclase and clinopyroxene. These magmas are linked to each other by fractional crystallization processes (Zanon and Frezzotti 2013; Zanon et al. 2020).

Basalts show an enrichment in light Rare Earth Elements (REE), as compared to middle and heavy REE ascribed to a low degree of partial melting of an enriched mantle source in the garnet stability field (Franca et al. 2006; Prytulak and Elliott 2009; Elliott et al. 2007; Beier et al. 2012; Zanon and Frezzotti 2013; Bourdon et al. 2005; Métrich et al. 2014; Waters et al. 2019).

\section{Samples description}

In this work, we studied clinopyroxenes extracted from seven basalts representative of the recent activity of the central volcano. Five of these rock samples (Pic22, Pic32, Pic43, Pic59, Pic64) are lavas erupted from lateral vents 
Fig. 2 Total-alkali vs. silica classification diagram for the Azores rocks. Literature data (LD) from GEOROC database

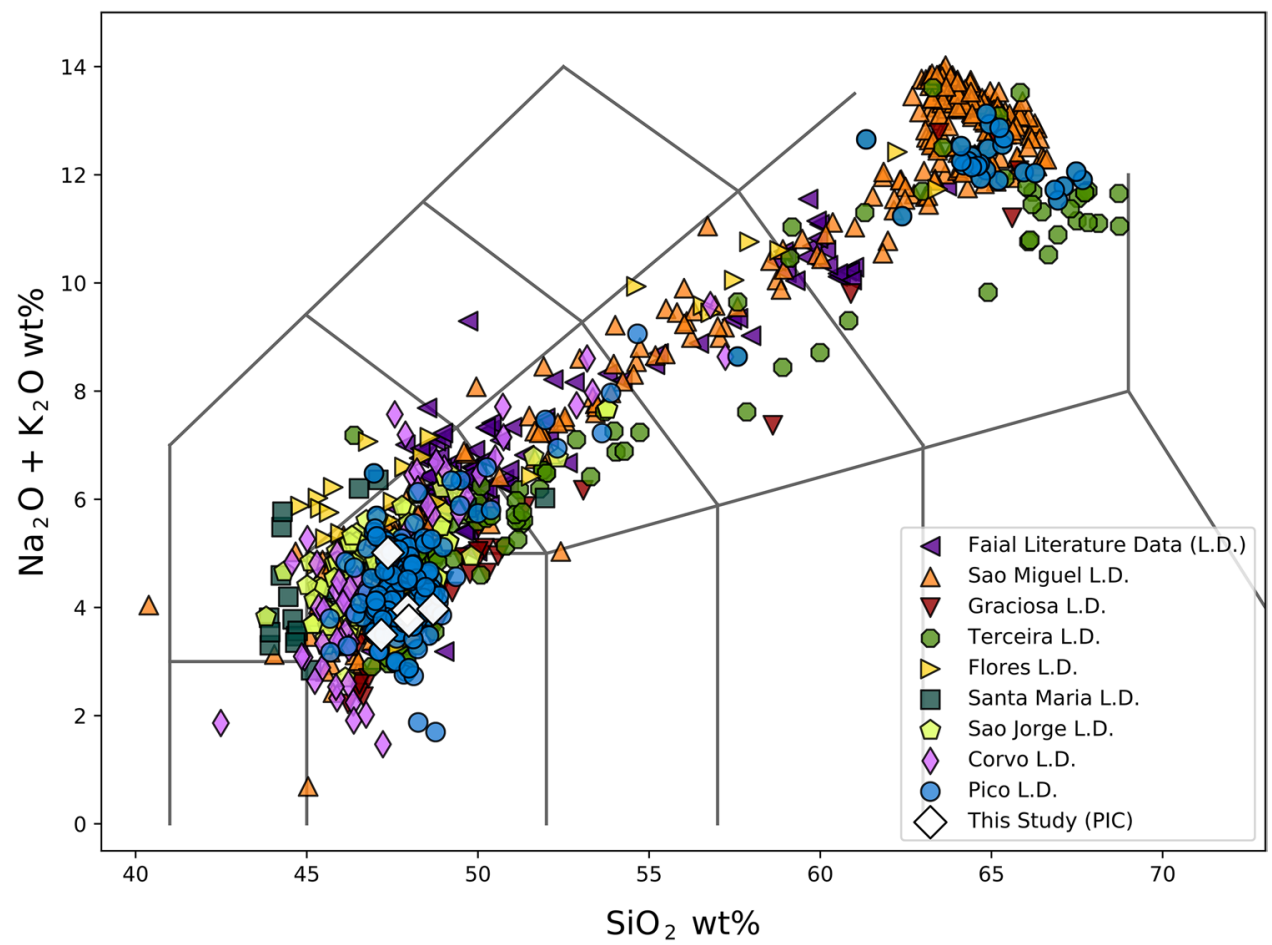

at low altitudes in a timeframe spanning the last $40 \mathrm{ka}$ (Nunes 1999; Zanon et al. 2020), Pic61 is a rheomorphic lava sampled nearby the summit crater rim and generated about 740 years before present by an episode of lava fountain (Zanon et al. 2020). 1718 sample is a clinopyroxene fallout originated during small size lava fountains from the vent of the 1718 eruption. The main data are resumed in supplementary data Table $\mathrm{S} 1$ and sampling locations are shown in Fig. 1.

The studied lavas are highly porphyritic with an average crystal content of $\sim 38 \mathrm{vol} \%$ dominantly consisting of pyroxene and olivine, both as large antecrysts, megacrysts and phenocrysts.

Olivine phenocrysts and antecrysts (Fo78-86) are present in all lava samples with a modal content ranging from 4 to $14 \%$. Crystals are commonly euhedral and frequently contain fluid and melt inclusions. Spinels are present only in the most Fo-rich grains, while oxides are common in all the other crystals. Glomeroporphyritic aggregates of clinopyroxenes are present in some samples. Microphenocrysts (average Fo86 \pm 3 ) are present only in three lava samples with $\leq 2 \%$ modal abundance and do not contain fluid and melt inclusions.

Perfectly euhedral diopside megacrysts $\left(\mathrm{Wo}_{40-43} \mathrm{Fs}_{6-8}\right.$ $\mathrm{En}_{40-45}$ ) are present in the fallout deposit from the 1718 eruption and constitute $\sim 52 \%$ in volume of the rheomorphic lava. Some of these crystals show disequilibrium features due to incipient melting or reaction, patchy zoning and embayments. Many crystals show oscillatory zoning at the 50-80 microns towards the rim. All these zoned crystals coexist with unzoned phenocrysts/antecrysts diopsides. Smaller phenocrysts/antecrysts represent the $13-19 \%$ in volume of lavas and are diopsides $\left(\mathrm{Wo}_{36-41}\right.$ $\left.\mathrm{Fs}_{3-10} \mathrm{En}_{37-47}\right)$. Oscillatory zoning is present in few crystals. Both megacrysts and phenocrysts host fluid and melt inclusions. Microphenocrysts (1-7 vol\%) are frequently subhedral with a composition matching that of the phenocrysts.

Plagioclases (average An66 \pm 1 ) are present as microphenocrysts (150-400 $\mu \mathrm{m})$ only in a single sample, oxides and apatites are minor phases. Intergranular to intersertal groundmass consists of olivine and clinopyroxene, ilmenite or Ti-magnetite, occasional plagioclase, plus eventual glass. The rheomorphic lava (or autoclastic lava) is the last eruptive event originated by the summit crater before collapsing, as it is the last unit in the stratigraphy there. This lava shows an extremely high crystal content (70-75 vol\%) consisting of aggregates of very large euhedral clinopyroxenes (frequently $>1.5 \mathrm{~cm}$ in length) and olivines $(0.2-0.4 \mathrm{~cm})$ welded by a reddish and partially glassy groundmass. All these lavas correspond to the type-A described in Zanon et al. (2020) and analysed in Zanon and Frezzotti (2013).

Clinopyroxenes from the pyroclastic fallout originating during the 1718 eruption have been directly hand-picked from the field deposit. Sampling site is a dirt road at a short distance from the lowermost vent of the fissure. Loose euhedral clinopyroxenes are numerous and constitute a thin blanket together with small lapilli and lava lithics. 
We handpicked clinopyroxenes of size from $\sim 0.5$ up to $1.5 \mathrm{~cm}$ from gently crushed lavas or directly from tephra fallout. From each sample we extracted various clinopyroxene crystals with particular attention to avoid complex zoned minerals.

\section{Experimental methods}

\section{Single-crystal X-ray diffraction}

Six clinopyroxene crystals (Pic43cpx, Pic61cpx, Pic22cpx, Pic32cpx, Pic59cpx, Pic64cpx) from lava samples were oriented by single-crystal X-ray diffraction, whereas the large euhedral crystal from the sample $1718 \mathrm{cpx}$ was oriented by aid of well-developed morphology. Crystals were mounted on a goniometric head for the single-crystal diffractometer Philips Pw1100 (Dept. Physics and Geology, University of Perugia) where, by applying the orientation matrix of each sample, crystallographic planes (100) and (010) were oriented and then glued directly on a glass plate.

A fragment of the crystals used for the FTIR measurements was used to collect XRD data. Data collection was performed on the Xcalibur diffractometer (Rigaku-Oxford diffraction, at the Dept. Physics and Geology, University of Perugia) up to $\theta=30^{\circ}$ by using graphite monochromatized $\mathrm{MoK} \alpha$ radiation. Anisotropic structural refinements were carried out in the $C 2 / c$ space group by using Shelxl (Sheldrick 2008) software. Details of the data collection and refinement are reported in Table S2 (supplementary material). In the refinements, we used partly ionized scattering factors $\left(\mathrm{Si}^{2.5+}, \mathrm{O}^{1.5-}\right.$, a mixed $\mathrm{Mg}^{2+} / \mathrm{Al}^{3+}$ and mixed $\mathrm{Ca}^{2+} /$ $\mathrm{Na}^{+}$) and occupancies of $\mathrm{Mg}$ and $\mathrm{Fe}^{2+}$ in $\mathrm{M} 1$ and $\mathrm{Ca}$ in M2 were refined. In all samples a residue peak in the electron density map occurred early in the refinements cycles at around $0.6 \AA$ from the $\mathrm{M} 2$ sites, thus the occupancy of $\mathrm{Fe}^{2+}$ in the M2' site was refined as described in Nazzareni et al. (2011). Final discrepancy factors R1 range between 1.7 and $3.2 \%$ (Table S2).

\section{Electron microprobe analyses}

Major elements of a second set of clinopyroxene crystals were analysed with a JEOL 8200 Super Probe electron microprobe by WDS at the Department of Earth Sciences Ardito Desio, University of Milan, Italy. A spot size of $1 \mu \mathrm{m}$ with a beam current of $5 \mathrm{nA}$ and $15 \mathrm{kV}$ was used throughout the measurements. Counting times were $30 \mathrm{~s}$ on the peak and $10 \mathrm{~s}$ on each background. Natural and synthetic mineral were used as standards for $\mathrm{Si}, \mathrm{Ca}, \mathrm{Al}$ (Grossular); $\mathrm{Na}$ (Omphacite); Ti (Ilmenite); Mn (Rhodonite); K (K-Feld); Mg (Olivine 153); Cr (pure Cr); Fe (Fayalite 143); P (Apatite); $\mathrm{Ni}$ (Niccolite). Accuracy is within $2 \%$ at $2 \sigma$. Raw data were corrected applying a Phi-Rho-Z quantitative analysis program. Typical detection limit for each element is $0.01 \%$. The relative errors are better than $6 \%$ for $\mathrm{P}_{2} \mathrm{O}_{5}$ and $\mathrm{K}_{2} \mathrm{O}$ and better than $3 \%$ for all the other major elements.

An average over up to five point analyses measured at the core of crystals are reported in Tables S3. Table 1 lists the final site occupancy assignments based on considerations of both microprobe and refinement results, the agreement of structural and chemical data expressed by the difference in the mean electron numbers (m.e.n.) was less than half electron.

\section{Laser ablation-inductively coupled plasma-mass spectrometry}

Trace element compositions of the second set of clinopyroxene crystals were estimated by laser ablation-inductively coupled plasma-mass spectrometry at the Department of Physics and Geology, University of Perugia. The instrumentation consisted in a Teledyne Photon Machine G2 laser ablation device coupled to a Thermo Fischer Scientific iCAP $\mathrm{Q}$ quadrupole mass spectrometer. A circular $65 \mu \mathrm{m}$ spot size, a repetition rate of $8 \mathrm{~Hz}$, and a laser fluence of $\sim 3.5 \mathrm{~J} \mathrm{~cm}^{-1}$ have been utilized. Ablation times were $\sim 50$ s per spot, preceded by a $30 \mathrm{~s}$ background measurement and followed by $30 \mathrm{~s}$ of washout. Data reduction was performed by the Iolite 3 software (Paton et al. 2011). The NIST SRM 610 (Pearce et al. 1997) glass and the USGS BCR2G (Wilson 1997) reference materials were used as calibrator and quality control, respectively. Si was used as internal standard. Under the reported analytical conditions, the precision is better than $10 \%$ for concentrations above $\sim 0.1 \mathrm{ppm}$, and better than $5 \%$ above 2 ppm; accuracy is always better than 10\% (Petrelli et al. 2016a, b). An average over 5 analyses are reported in Table S3 (supplementary material).

\section{Polarized infrared spectroscopy}

Polarized infrared spectra were measured using a Bruker Equinox 55 Fourier-Transform spectrometer equipped with a tungsten light source, a Si-coated $\mathrm{CaF}_{2}$ beam splitter, a wire-grid polarizer (KRS-5) and an InSb detector at the Department of Geological Sciences (Natural History Museum, Stockholm). The spectra were acquired in the range $2000-5000 \mathrm{~cm}^{-1}$, polarized along the directions of the main refractive indices $(\alpha, \beta$ and $\gamma$ ) on doubly polished crystal plates oriented parallel to (010) and (100), with thicknesses from 200 to $550 \mu \mathrm{m}$. Measuring areas were masked by circular apertures with diameters in the range 100-300 $\mu \mathrm{m}$, carefully avoiding inclusions and cracks.

Spectra were baseline-corrected by a polynomial function and the $\mathrm{OH}$ bands fitted using the Peakfit software to determine the absorption area of the $\mathrm{OH}$ bands. Water 
Table 1 Clinopyroxenes cation partitioning calculated on 6 oxygens atoms (in a.f.u.)

\begin{tabular}{|c|c|c|c|c|c|c|c|}
\hline & Pic32cpx & Pic43cpx & Pic59cpx & Pic61cpx & Pic64cpx & $1718 \mathrm{cpx}$ & Pic 22cpx \\
\hline \multicolumn{8}{|l|}{$\mathrm{T}$ site } \\
\hline $\mathrm{Si}$ & 1.863 & 1.883 & 1.925 & 1.918 & 1.913 & 1.870 & 1.88 \\
\hline $\mathrm{Al}^{\mathrm{IV}}$ & 0.137 & 0.117 & 0.075 & 0.082 & 0.047 & 0.130 & 0.11 \\
\hline \multicolumn{8}{|l|}{ M1 site } \\
\hline $\mathrm{Al}^{\mathrm{VI}}$ & 0.063 & 0.044 & 0.034 & 0.037 & 0.055 & 0.05 & 0.056 \\
\hline $\mathrm{Ti}$ & 0.027 & 0.026 & 0.009 & 0.017 & 0.014 & 0.030 & 0.023 \\
\hline $\mathrm{Fe}^{3+}$ & 0.03 & 0.034 & 0.022 & 0.024 & 0.023 & 0.028 & 0.026 \\
\hline $\mathrm{Fe}^{2+}$ & 0.039 & 0.048 & 0.052 & 0.054 & 0.065 & 0.070 & 0.0517 \\
\hline $\mathrm{Cr}$ & 0.015 & 0.018 & 0.027 & 0.018 & 0.013 & 0.021 & 0.031 \\
\hline $\mathrm{Mn}$ & 0.001 & 0.001 & 0.001 & 0.002 & 0.001 & 0.002 & 0.0009 \\
\hline $\mathrm{Mg}$ & 0.825 & 0.829 & 0.854 & 0.848 & 0.827 & 0.799 & 0.8181 \\
\hline \multicolumn{8}{|l|}{ M2 site } \\
\hline $\mathrm{Ca}$ & 0.813 & 0.848 & 0.861 & 0.864 & 0.871 & 0.860 & 0.8524 \\
\hline $\mathrm{Na}$ & 0.024 & 0.03 & 0.026 & 0.03 & 0.031 & 0.030 & 0.032 \\
\hline $\mathrm{Fe}^{2+}$ & 0.109 & 0.059 & 0.043 & 0.048 & 0.042 & 0.048 & 0.0548 \\
\hline $\mathrm{Mg}$ & 0.053 & 0.062 & 0.07 & 0.057 & 0.056 & 0.061 & 0.0596 \\
\hline $\mathrm{Mn}$ & 0.002 & 0.002 & 0.001 & 0.001 & 0.001 & 0.001 & 0.0011 \\
\hline \multicolumn{8}{|l|}{ m.e.n } \\
\hline chem & 33.5 & 33.3 & 33.0 & 33.1 & 33.1 & 33.6 & 33.4 \\
\hline XRD & 33.4 & 32.6 & 33.0 & 32.8 & 32.6 & 32.9 & 33.2 \\
\hline Dm.e.n & 0.10 & 0.73 & 0.00 & 0.32 & 0.48 & 0.66 & 0.16 \\
\hline$T_{\mathrm{c}}\left({ }^{\circ} \mathrm{C}\right)$ & 554 & 755 & 903 & 814 & 928 & 949 & 791 \\
\hline
\end{tabular}

Partition between ferric and ferrous iron based on Mössbauer analysis. Closure temperature (Tc), mean electrons number (m.e.n.) from chemical (chem.) and single-crystal X-ray diffraction (XRD) and their difference (Dm.e.n.) are also reported concentrations were then calculated from the sum of the integrated absorption areas obtained in the $\alpha, \beta$, and $\gamma$ directions $\left(A_{\mathrm{tot}}=A \alpha+A \beta+A \gamma\right)$ according to the Beer-Lambert law.

Potential uncertainties for calculated water contents can arise from baseline definition and measurements of the crystal thickness. However, due to the good quality of the spectra obtained after rehydration, and the relatively large thickness of the crystals, a maximum error of $\pm 10 \%$ is assumed for the precision of the absorption areas. In addition, the uncertainty regarding the accuracy of the values due to the calibration of absorption coefficients is estimated to another $\pm 10 \%$ (cf. Libowitzky and Rossman 1997), resulting in an overall uncertainty of $\pm 20 \%$ for the calculated clinopyroxene water contents.

\section{Thermal annealing}

All samples were thermally annealed under hydrogen atmosphere (at $1 \mathrm{~atm}$ ) at either $700{ }^{\circ} \mathrm{C}$ or $800{ }^{\circ} \mathrm{C}$ for different time in a horizontal furnace equipped with a quartz-glass tube at the Department of Geological Sciences (Natural History Museum, Stockholm). Crystals were placed in a golden sample holder and pushed into the centre of the furnace. The run was terminated by pushing the sample holder out of the hot spot zone. A Pt100-Pt90Rh10-thermocouple placed directly above the samples was used to control the temperature values, which are estimated to be correct within $\pm 2{ }^{\circ} \mathrm{C}$. All samples were treated at $700{ }^{\circ} \mathrm{C}$ during different steps by increasing time up to $65 \mathrm{~h}$. Pic22cpx, Pic32cpx Pic61cpx were then additionally treated at $800{ }^{\circ} \mathrm{C}$ for $42-148 \mathrm{~h}$. $1782 \mathrm{Cpx}$ was treated only at $800{ }^{\circ} \mathrm{C}$. The time of the heating experiments and the number of steps to reach a steady $\mathrm{OH}$ content were based on the change of the $\mathrm{OH}$ bands in the FTIR spectra recorded after each heating step (Table 2).

\section{Mössbauer spectroscopy}

Mössbauer analysis was performed both on untreated and hydrogen-treated crystals using a conventional spectrometer system operated in constant-acceleration mode. For the untreated samples, material was handpicked from the remaining crystals, which was soaked in acetone and grinded. The sample powder was then mixed with an acrylic resin powder, and pressed to self-supporting disc under mild heating $\left(150^{\circ} \mathrm{C}\right)$. Spectra were collected at room-temperature using a standard ${ }^{57} \mathrm{Co}$ source in $\mathrm{Rh}$ matrix with a nominal activity of $50 \mathrm{mCi}$. The spectra were acquired over 1024 channels in the velocity range -4.5 to $+4.5 \mathrm{~mm} / \mathrm{s}$ and calibrated against an $\alpha$-Fe foil. 
Table 2 Water content in ppm of the clinopyroxenes before and after each treatment in H-atmosphere

\begin{tabular}{|c|c|c|c|c|c|c|c|c|c|}
\hline Temperature & Time (h) & $1718 \mathrm{cpx}$ & $1718 \mathrm{cpx}$ & Pic64cpx & Pic22cpx & Pic32cpx & Pic43cpx & Pic61cpx & Pic59cpx \\
\hline & & Core & Rim & Core & Core & Core & Core & Core & Core \\
\hline Untreated & - & $120(24)$ & $131(26)$ & $91(18)$ & $16(3)$ & - & - & - & - \\
\hline \multirow[t]{3}{*}{$700^{\circ} \mathrm{C}$} & 7 & & $189(38)$ & 109 & 66 & 96 & 48 & 57 & 44 \\
\hline & 24 & & & 148 & 85 & 112 & 95 & 100 & 91 \\
\hline & 65 & & & $157(31)$ & 122 & 144 & $124(25)$ & 121 & 93 (18) \\
\hline \multirow[t]{5}{*}{$800^{\circ} \mathrm{C}$} & (+) 42 & & & & 134 & 151 & & 154 (31) & \\
\hline & (+) 83 & & & & $141(28)$ & 167 & & & \\
\hline & (+) 148 & & & & & $170(34)$ & & & \\
\hline & 65 & 180 & & & & & & & \\
\hline & 131 & $182(36)$ & & & & & & & \\
\hline
\end{tabular}

Bold values are the final values used for further calculations

Values obtained using the Libowitzky and Rossman (1997) calibration are reported. All clinopyroxenes were treated at $700{ }^{\circ} \mathrm{C}$ by increasing time up to $65 \mathrm{~h}$. Pic22cpx, Pic32cpx Pic61cpx were then additionally treated at $800{ }^{\circ} \mathrm{C}$ for $42-148 \mathrm{~h} .1782 \mathrm{Cpx}$ was treated only at $800{ }^{\circ} \mathrm{C}$. The $(+)$ sign means additional treatments at different temperature $\left(800^{\circ} \mathrm{C}\right)$

For the treated samples, the Mössbauer absorbers were made from parts of the crystals used for the FTIR measurements. Since the amount of this material was too small to produce the discs described above, the powdered sample was mixed with a thermoplastic resin and molded by hand on a piece of tape under heat, to obtain a mm-sized absorber. Spectra were collected using a ${ }^{57}$ Co point-source in Rh matrix with a nominal activity of $10 \mathrm{mCi}$ and an active area of $0.5 \mathrm{~mm}$ diameter, with other experimental conditions as described above.

The Mössbauer spectra were folded and fitted with one $\mathrm{Fe}^{3+}$ and two $\mathrm{Fe}^{2+}$ quadrupole doublets by means of a least squares fitting program (Jernberg and Sundqvist 1983). The obtained hyperfine parameters are typical for diopsideaugite clinopyroxene. The fitting parameters, centroid shift $\delta$, quadrupole splitting $\Delta E_{Q}$, full width at half maximum $\Gamma$, are reported in Table 3.

\section{Clinopyroxene thermo-barometry}

\section{Barometry based on clinopyroxene unit cell and octahedral M1 volumes}

Following the same approach reported in Nazzareni et al. (2011), we used the clinopyroxene geobarometer based on crystallographic and crystal-chemical characteristics of the clinopyroxene phase to infer its pressure of crystallisation (Nazzareni et al. 1998; Nimis 1999; Nimis and Ulmer 1998). In clinopyroxene, a linear relationship exists between unit cell and octahedral M1 volumes with pressure of crystallization: at high pressure both volumes have small values that increase by decreasing pressure irrespective to magma bulk composition (see Dal Negro et al. 1989). For the calculations, we used the structural data obtained by the single-crystal X-ray diffraction.

\section{Thermobarometric calculations based on the chemistry of the clinopyroxene-liquid pairs}

Thermobarometric estimations based on the chemistry of clinopyroxene-liquid pairs were performed using the calibrations reported in Putirka (2008). In agreement with Hammer et al. (2016), we reported the results of different calibrations, including the equations T1 (Putirka et al. 1996), T33 (Putirka 2008), and T34 (Putirka 2008) for the temperature and the equations P1 (Putirka et al. 1996), 30 (Putirka 2008), 32a (Putirka 2008) an 32b (Putirka 2008) for the pressure. As a liquid composition, we utilized the average value of basalts for the Azores extracted from a AZORES.cvs file from GEOROC, and reported as supplementary material (Table S4). We checked for the cpx-liquid pair's equilibrium by using the $\Delta \mathrm{DiHd}$ parameter, with threshold at 0.1 .

\section{Results and discussion}

\section{Clinopyroxene crystal chemistry}

The studied clinopyroxenes are optically homogeneous diopside with a limited chemical variability $\left(\mathrm{Wo}_{45-46} \mathrm{En}_{45-48}\right.$ $\left.\mathrm{Fs}_{6-9}\right)$ (Tables 1-S3). Crystals have low $\mathrm{Cr}_{2} \mathrm{O}_{3}(0.5-1.08$ $\mathrm{wt} \%)$ and $\mathrm{TiO}_{2}(0.5-1.24 \mathrm{wt} \%)$. Ferric and ferrous iron ratio has been calculated using the Mössbauer $\mathrm{Fe}^{3+} / \mathrm{Fe}_{\text {tot }}$ values: $\mathrm{Fe}_{2} \mathrm{O}_{3}$ varies from 1.23 to $0.79 \mathrm{wt} \%$ and $\mathrm{FeO}$ from 4.30 to $3.06 \mathrm{wt} \%$ (Tables 3, S3).

We observed a coupled substitution of $\mathrm{Al}^{\mathrm{IV}}$ for $\mathrm{Si}$ in $\mathrm{T}$ site, $\mathrm{Al}^{\mathrm{VI}}, \mathrm{Ti}^{4+}$ and $\mathrm{Fe}^{3+}$ for $\mathrm{Mg}$ in $\mathrm{M} 1$ site and $\mathrm{Na}$ for $\mathrm{Ca}$ 
Table 3 Mössbauer parameters for the Pico clinopyroxenes

\begin{tabular}{|c|c|c|c|c|c|c|}
\hline Sample & $\delta$ & $\Delta E_{\mathrm{Q}}$ & $\Gamma$ & $\%$ Area & Assignment & Source \\
\hline \multirow[t]{3}{*}{ Pic22cpx } & 1.14 & 2.28 & 0.33 & 32.2 & $\mathrm{Fe}^{2+}$ & \multirow[t]{3}{*}{ Standard } \\
\hline & 1.14 & 1.92 & 0.24 & 46.8 & $\mathrm{Fe}^{2+}$ & \\
\hline & 0.44 & 0.71 & 0.41 & 20.9 & $\mathrm{Fe}^{3+}$ & \\
\hline \multirow[t]{3}{*}{ Pic32cpx } & 1.14 & 2.28 & 0.33 & 32.2 & $\mathrm{Fe}^{2+}$ & \multirow[t]{3}{*}{ Standard } \\
\hline & 1.14 & 1.93 & 0.23 & 47.7 & $\mathrm{Fe}^{2+}$ & \\
\hline & 0.44 & 0.70 & 0.45 & 20.1 & $\mathrm{Fe}^{3+}$ & \\
\hline \multirow[t]{3}{*}{ Pic32cpx, treated } & 1.14 & 2.29 & 0.30 & 33.0 & $\mathrm{Fe}^{2+}$ & \multirow[t]{3}{*}{ Point } \\
\hline & 1.14 & 1.93 & 0.24 & 50.9 & $\mathrm{Fe}^{2+}$ & \\
\hline & 0.48 & 0.68 & 0.55 & 16.1 & $\mathrm{Fe}^{3+}$ & \\
\hline \multirow[t]{3}{*}{ Pic43cpx } & 1.13 & 2.30 & 0.31 & 30.1 & $\mathrm{Fe}^{2+}$ & \multirow[t]{3}{*}{ Standard } \\
\hline & 1.14 & 1.92 & 0.24 & 44.1 & $\mathrm{Fe}^{2+}$ & \\
\hline & 0.44 & 0.73 & 0.44 & 25.8 & $\mathrm{Fe}^{3+}$ & \\
\hline \multirow[t]{3}{*}{ Pic59cpx } & 1.13 & 2.25 & 0.32 & 31.3 & $\mathrm{Fe}^{2+}$ & \multirow[t]{3}{*}{ Standard } \\
\hline & 1.14 & 1.92 & 0.22 & 48.1 & $\mathrm{Fe}^{2+}$ & \\
\hline & 0.46 & 0.69 & 0.40 & 20.6 & $\mathrm{Fe}^{3+}$ & \\
\hline \multirow[t]{3}{*}{ Pic59, treated } & 1.13 & 2.30 & 0.32 & 32.6 & $\mathrm{Fe}^{2+}$ & \multirow[t]{3}{*}{ Point } \\
\hline & 1.14 & 1.93 & 0.24 & 45.0 & $\mathrm{Fe}^{2+}$ & \\
\hline & 0.43 & 0.72 & 0.40 & 22.4 & $\mathrm{Fe}^{3+}$ & \\
\hline \multirow[t]{3}{*}{ Pic61cpx } & 1.12 & 2.26 & 0.34 & 32.5 & $\mathrm{Fe}^{2+}$ & \multirow[t]{3}{*}{ Standard } \\
\hline & 1.14 & 1.91 & 0.23 & 46.3 & $\mathrm{Fe}^{2+}$ & \\
\hline & 0.46 & 0.71 & 0.38 & 21.2 & $\mathrm{Fe}^{3+}$ & \\
\hline \multirow[t]{3}{*}{ Pic61cpx, treated } & 1.14 & 2.28 & 0.30 & 31.6 & $\mathrm{Fe}^{2+}$ & \multirow[t]{3}{*}{ Point } \\
\hline & 1.14 & 1.91 & 0.23 & 47.7 & $\mathrm{Fe}^{2+}$ & \\
\hline & 0.44 & 0.71 & 0.49 & 20.7 & $\mathrm{Fe}^{3+}$ & \\
\hline \multirow[t]{3}{*}{ Pic64 } & 1.13 & 2.27 & 0.30 & 30.3 & $\mathrm{Fe}^{2+}$ & \multirow[t]{3}{*}{ Standard } \\
\hline & 1.14 & 1.92 & 0.22 & 50.9 & $\mathrm{Fe}^{2+}$ & \\
\hline & 0.45 & 0.71 & 0.39 & 18.8 & $\mathrm{Fe}^{3+}$ & \\
\hline \multirow[t]{3}{*}{ Pic64cpx, treated } & 1.14 & 2.29 & 0.30 & 33.0 & $\mathrm{Fe}^{2+}$ & \multirow[t]{3}{*}{ Point } \\
\hline & 1.15 & 1.92 & 0.23 & 49.2 & $\mathrm{Fe}^{2+}$ & \\
\hline & 0.44 & 0.69 & 0.44 & 17.8 & $\mathrm{Fe}^{3+}$ & \\
\hline \multirow[t]{3}{*}{$1718 \mathrm{cpx}$ core } & 1.15 & 2.31 & 0.34 & 32.3 & $\mathrm{Fe}^{2+}$ & \multirow[t]{3}{*}{ Standard } \\
\hline & 1.14 & 1.92 & 0.23 & 47.0 & $\mathrm{Fe}^{2+}$ & \\
\hline & 0.44 & 0.70 & 0.46 & 20.6 & $\mathrm{Fe}^{3+}$ & \\
\hline \multirow[t]{3}{*}{$1718 \mathrm{cpx}$ core, treated } & 1.14 & 2.27 & 0.30 & 31.8 & $\mathrm{Fe}^{2+}$ & \multirow[t]{3}{*}{ Point } \\
\hline & 1.15 & 1.93 & 0.23 & 47.8 & $\mathrm{Fe}^{2+}$ & \\
\hline & 0.42 & 0.64 & 0.49 & 20.4 & $\mathrm{Fe}^{3+}$ & \\
\hline \multirow[t]{3}{*}{ 1718cpx rim } & 1.13 & 2.35 & 0.33 & 34.8 & $\mathrm{Fe}^{2+}$ & \multirow[t]{3}{*}{ Standard } \\
\hline & 1.14 & 1.88 & 0.26 & 34.6 & $\mathrm{Fe}^{2+}$ & \\
\hline & 0.43 & 0.73 & 0.42 & 30.6 & $\mathrm{Fe}^{3+}$ & \\
\hline
\end{tabular}

The fitting parameters, centroid shift $\delta$, quadrupole splitting $\Delta E_{\mathrm{Q}}$, full width at half maximum $\Gamma$, and absorption area (expressed in percent) together with assignment to ferric or ferrous iron are reported. Standard or point source used for the measurement are also reported. The estimated error for the areas is $1 \%$

$\delta=$ centroid shift $(\mathrm{mm} / \mathrm{s}), \Delta E_{\mathrm{Q}}=$ quadrupole splitting $(\mathrm{mm} / \mathrm{s}), \Gamma=$ full width at half maximum $(\mathrm{mm} / \mathrm{s})$ in M2 site to charge balance the structure. The Ca-Eskola substitution $\left(\mathrm{Ca}_{0.5}[]_{0.5} \mathrm{Al} \mathrm{Si}_{2} \mathrm{O}_{6}\right)$, which has been shown to correlate with the $\mathrm{H}$ content in high-pressure pyroxene (omphacite, Skogby 2006), was not observed.

All the samples have a larger variation in incompatible elements than in Sc and other compatible elements
(Table S3). The Sc concentration ranges from 76 to $115 \mathrm{ppm}$, Ni from 204 to 264 ppm and Cr from 4327 to 7637 ppm. Nd varies from 3.5 to $11 \mathrm{ppm}, \mathrm{La}$ from 0.84 to $2.7 \mathrm{ppm}, \mathrm{Ce}$ from 3.31 to $9.23 \mathrm{ppm}, \mathrm{Zr}$ from 8.8 to $47 \mathrm{ppm}$, Y from 7.5 to $16 \mathrm{ppm}$ and $\mathrm{Sm}$ from 1.5 to $3.5 \mathrm{ppm}$. Mg\# correlates negatively with incompatible elements (REE, HFSE and Sr) and 
Fig. 3 Spider diagrams of Pico Volcano pyroxenes. Normalised to chondritic composition (McDonough and Sun 1995)

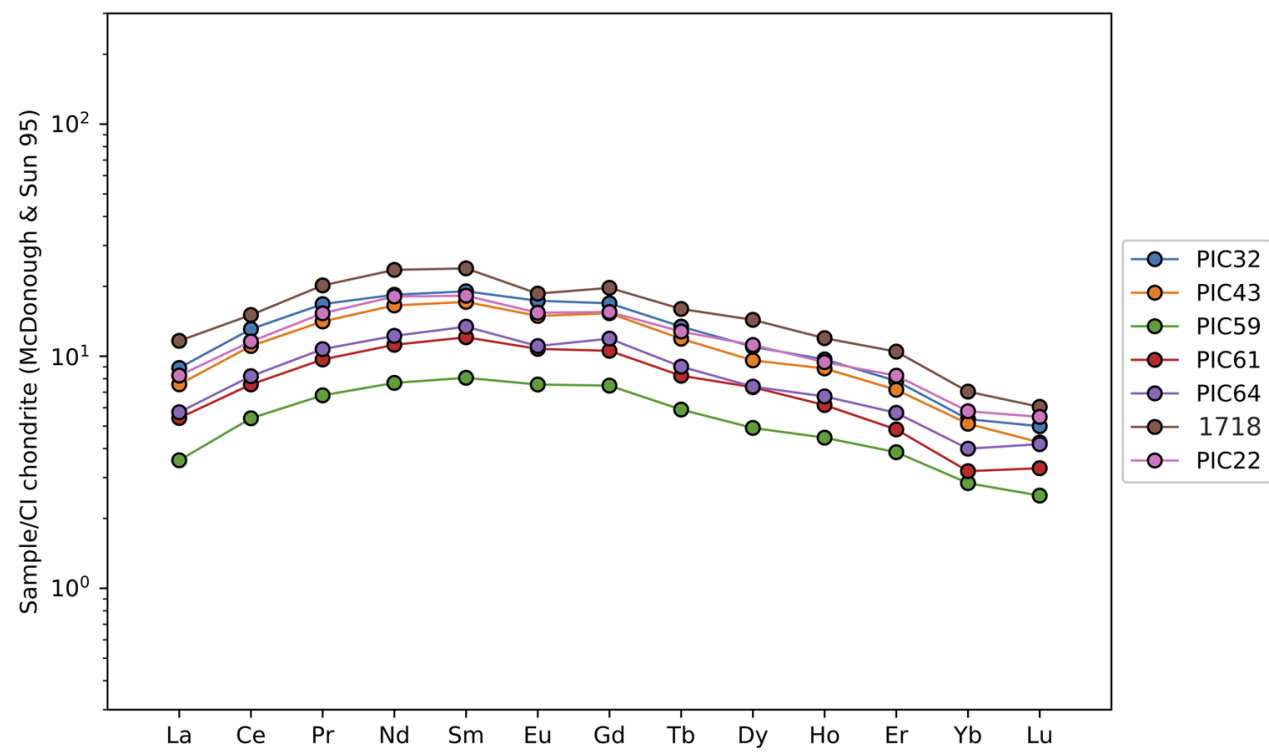

positively with compatible $\mathrm{Cr}$, Ni elements. $\mathrm{U}, \mathrm{Pb}$, Th and $\mathrm{Nb}$ show no correlation with Mg\# (Table S2). Clinopyroxenes 1718cpx, Pic32cpx and Pic22cpx have higher contents of REE than the other pyroxene samples, although with a similar distribution pattern. Pico Volcano clinopyroxenes have a similar trace elements distribution (Fig. 3), with a slight depletion in LREE relative to MREE for all the clinopyroxenes and a very slight negative anomaly of Eu in the REE pattern. The 1718cpx and Pic22cpx clinopyroxenes are the most enriched whereas Pic59cpx and Pic61cpx are the less enriched in REE given the same pattern in the spider diagram of Fig. 3.

From the application of the lattice strain model specific to mafic alkaline magmas (Mollo et al. 2018) to the chemical compositions of the studied Pico cpxs, it emerges that the predicted partition coefficients for the different REEs do not vary significantly among the investigated cpx-liquid compositions. As a consequence, we can infer that the observed trace element enrichments of 1718cpx, Pic22cpx and Pic64cpx result from chemical heterogeneities in the magmatic system, possibly due to parental magma primary differences, crystallization-related zonations, or the interaction with metasomatic agents at a different degree (Zanon and Frezzotti 2013; Larrea et al. 2014).

\section{Clinopyroxenes water content}

The IR spectra of diopside and augite normally show a characteristic set of bands in the $\mathrm{OH}$ region with a pleochroic scheme with one $\mathrm{OH}$ band around $3630-3640 \mathrm{~cm}^{-1}$ polarized in the $\alpha$ and $\beta$ directions and two bands around $3530 \mathrm{~cm}^{-1}$ and $3450 \mathrm{~cm}^{-1}$ with $\gamma>\alpha=\beta$ pleochroism (e.g. Skogby 2006). We observed these OH bands with varying intensity for samples $1718 \mathrm{cpx}$, Pic22cpx, Pic64cpx,

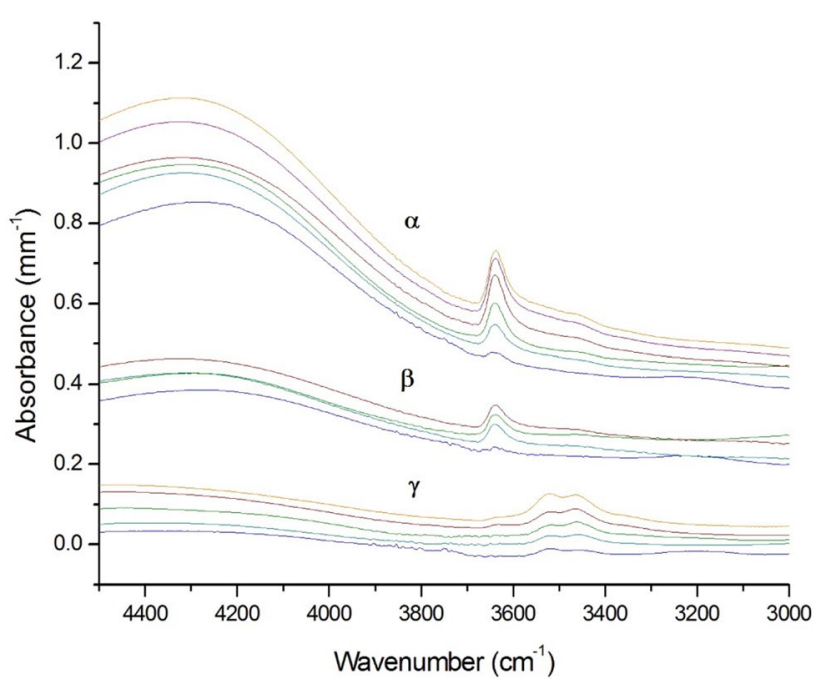

Fig. 4 Polarized IR spectra of pyroxene Pic22, with Ell $\alpha$ and Ell $\beta$ measured on the (010) crystal face and Ell $\gamma$ measured on the (100) face. Thickness of the sample in the (010) orientation is $320 \mu \mathrm{m}$ and in the (100) orientation $123 \mu \mathrm{m}$. Spectra are recorded before and after each treatment for all the three directions (bottom to top)

whereas these bands were very weak or absent for the other four samples (Fig. 4). We calculated the water contents by the integrated area of the $\mathrm{OH}$ bands derived from the IR spectral fitting using the calibration proposed by Libowitzky and Rossman (1997) (Table 2). This calibration takes into account the wavenumber dependence of the absorption coefficients and better applies to several natural pyroxenes as reported by Mosenfelder and Rossman (2013).

Pic22cpx, 1718cpx and Pic64cpx had a $\mathrm{H}_{2} \mathrm{O}$ content from 16 to $120 \mathrm{ppm}$, whereas the other Pico samples had very weak to absent $\mathrm{OH}$ bands that prevent a reasonable 
determination of the $\mathrm{OH}$ bands absorption area and hydrogen content. The variable amount of hydrogen content cannot be explained by a chemical variation among the studied clinopyroxenes: they all are diopside $\left(\mathrm{Wo}_{45-46} \mathrm{En}_{45-48} \mathrm{Fs}_{6-9}\right)$ with very similar chemical compositions (Tables 1, S2). However, 1718cpx has the highest water content as can be expected for a pyroclastic occurrence due to the fast quenching limiting hydrogen loss.

Several processes starting from a possible residing in magma chamber(s), the ascent to surface and/or post-eruption may all be potential hydrogen loss steps (e.g. Peslier et al. 2002; Wade et al. 2008). In phenocrysts, the $\mathrm{H}$ loss often occurs more extensively at the rim than at the core (Ferriss et al. 2016), thus to minimize potential underestimation of $\mathrm{H}$, we measured the FTIR spectra at the core of our crystals, nevertheless most of them showed to be dry. In the case of the $1718 \mathrm{cpx}$ "large" crystal the difference in the $\mathrm{H}_{2} \mathrm{O}$ content measured at the core $(120 \mathrm{ppm})$ and at the rim $(131 \mathrm{ppm})$ is $\pm 11 \mathrm{ppm}$, a value within the analytical error (Table 2).

Considering post-eruptive processes, we expect that in slowly cooled lavas the $\mathrm{H}$ loss process may be extensive. To assess the cooling rate of our lavas we can utilize the same clinopyroxene phenocrysts because the subsolidus process of $\mathrm{Mg}$ and $\mathrm{Fe}^{2+}$ cations intracrystalline exchange between the M1 and M2 crystallographic sites in this phase is temperature and time dependent (Dal Negro et al. 1982). The closure temperature $\left(T_{\mathrm{c}}\right)$ at which this exchange reaction ceases is related to the pyroxene-bearing host rock cooling rate (Murri et al. 2018). A high (low) $T_{\mathrm{c}}$ corresponds to a fast (slow) cooling rate of the pyroxene-bearing host rock.

We calculated the $T_{\mathrm{c}}$ for Pico pyroxenes using the calibration of Murri et al. (2018) obtaining a quite high cooling rate for the cpx-host lavas $\left(T_{\mathrm{c}}=755-928^{\circ} \mathrm{C} \pm 20^{\circ} \mathrm{C}\right)$ except for Pic32cpx that has a low $T_{\mathrm{c}}=554{ }^{\circ} \mathrm{C}\left( \pm 20{ }^{\circ} \mathrm{C}\right)$ and consequently a low cooling rate (Table 1 ). The highest $T_{\mathrm{c}}$ of $949^{\circ} \mathrm{C}$ was recorded by the $1718 \mathrm{cpx}$ pyroxene, as expected for a fast cooled material like a pyroclastic fall.

We expected that if the loss of $\mathrm{H}$ was uniquely a posteruptive process at high cooling rates we had a low $\mathrm{H}$ loss. In our case we did not observed a clear correlation between host rocks cooling rates and pyroxene water content (Fig. 5) suggesting that all the studied pyroxenes suffered dehydrogenation mainly before eruption.

\section{Water content after rehydration}

In order to assess whether we have sampled different portions of magma with different water content or clinopyroxene suffered of $\mathrm{H}$ loss pre- or post-eruption, we carried out annealing experiments under $\mathrm{H}_{2}$ gas flux up to saturation. In the pyroxene structure $\mathrm{H}$ is associated to point defects, and the charge deficiency is compensated by coupled substitutions such as tetrahedral $\mathrm{Si}-\mathrm{Al}$ exchange and/or a change in the oxidation state of a neighbouring element (e.g. Fe). The hydrogen loss can thus be achieved by iron oxidation reaction:
Fig. $5 \quad \mathrm{H}_{2} \mathrm{O}$ content vs $T_{\mathrm{c}}$ (closure temperature).Grey triangle symbols: untreated pyroxene. Black square symbols: treated pyroxene. See text for discussion

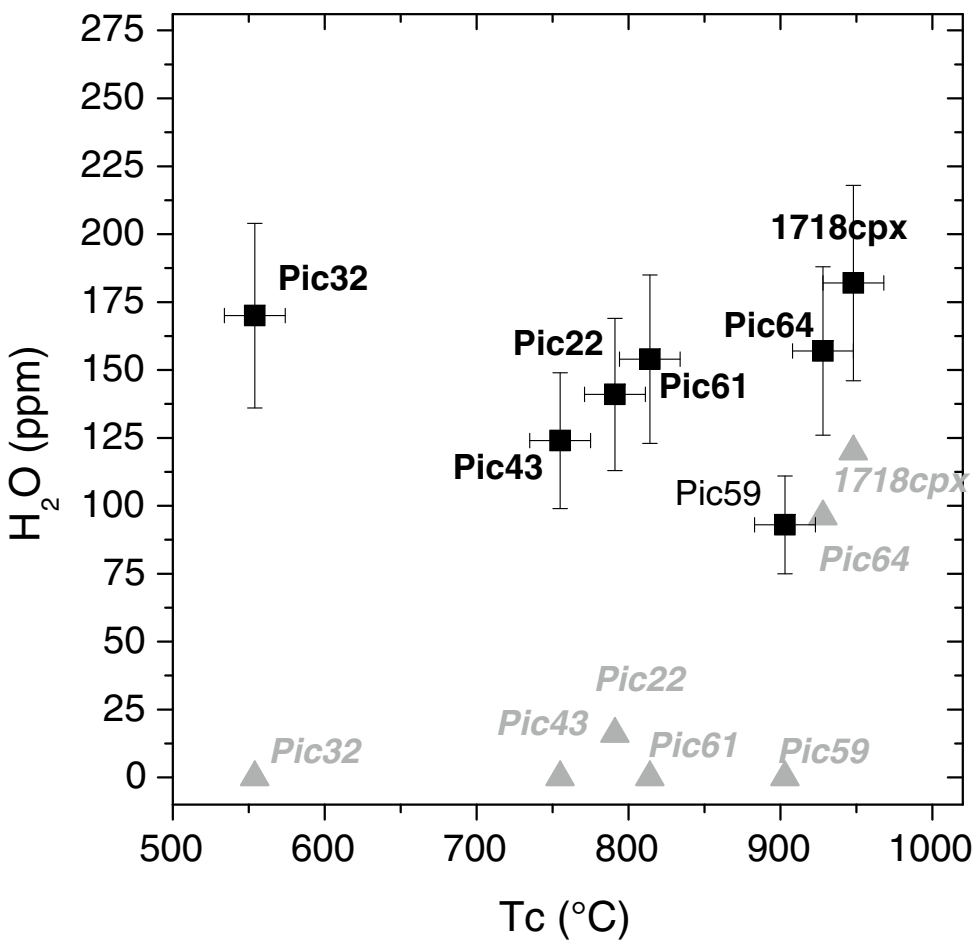


$\mathrm{Fe}^{2+}+\mathrm{OH}^{-}=\mathrm{Fe}^{3+}+\mathrm{O}^{2-}+1 / 2 \mathrm{H}_{2}$

The redox-dehydration reaction has been shown to be reversible to large extents (Weis et al. 2016, 2017), and it is thereby possible to rehydrate samples that have lost $\mathrm{H}$ by annealing experiments. During the H-loss process by the redox reaction the point defects originally associated with $\mathrm{OH}$, that have a much slower kinetic diffusion rate (Cherniak and Dimanov 2010), are retained in the structure. In order not to change the overall defect chemistry of the samples, such experiments need to be performed at relatively low temperatures $\left(\sim 700-800{ }^{\circ} \mathrm{C}\right.$; Weis et al. 2016, 2017).

We performed several heating steps on Pico clinopyroxenes at $700{ }^{\circ} \mathrm{C}$ and $800{ }^{\circ} \mathrm{C}$ up to $148 \mathrm{~h}$ to reach hydrogen saturation (Table 2 and Fig. 5). Experiments were repeated with prolonged duration until two similar results in $\mathrm{OH}$ content were observed for each sample. All the Pico clinopyroxenes had an increase of the $\mathrm{OH}$ bands intensity in their IR spectra, with a corresponding increase in water contents arriving at final values of 93-182 ppm $\mathrm{H}_{2} \mathrm{O}$ (Table 2). In particular, the "dry" clinopyroxenes recovered $\mathrm{H}$ contents to become comparable to the values measured for the "waterrich" 1718cpx untreated crystal (Table 2).

Mössbauer spectra were measured before and after the annealing experiments to quantify the $\mathrm{Fe}^{2+} / \mathrm{Fe}^{3+}$ ratio (Fig. 6, Table 3). Apart from the highest $\mathrm{Fe}^{3+} / \mathrm{Fe}_{\text {tot }}$ ratio (25.8\% in sample Pic43cpx), untreated Pico clinopyroxenes have a similar $\mathrm{Fe}^{3+} / \mathrm{Fe}_{\text {tot }}$ ratio (min $18.8 \%$, max $21.2 \%$, average $20.4 \%$ ) despite the different intensity of $\mathrm{OH}$ bands in the IR spectra.

After the annealing experiments a minor decrease in the $\mathrm{Fe}^{3+} / \mathrm{Fe}_{\text {tot }}$ ratio was observed for all samples except for Pic59 cpx (Table 3). This change is often within the estimated

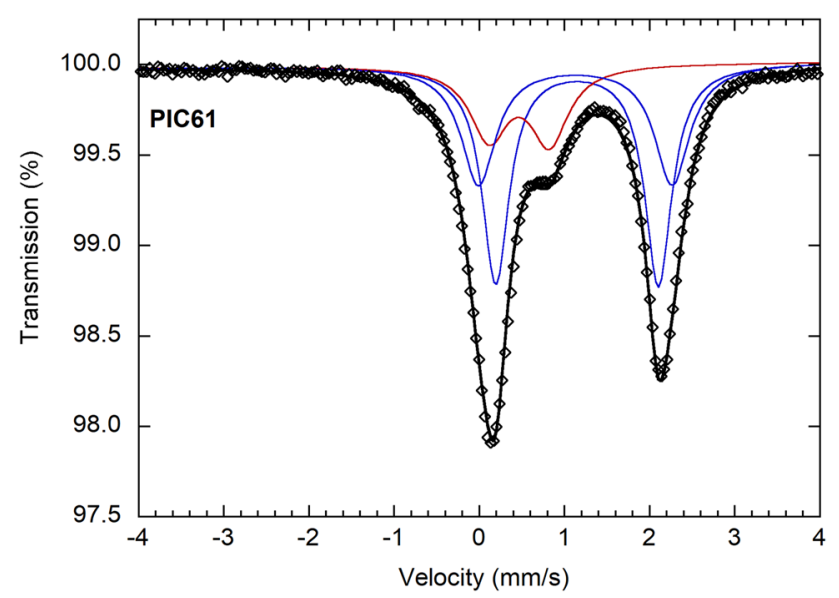

Fig. 6 Representative ${ }^{57} \mathrm{Fe}$ Mössbauer spectrum of the investigated clinopyroxene samples (Pic61cpx, untreated) obtained at roomtemperature. Fitted absorption doublets assigned to $\mathrm{Fe}^{2+}$ and $\mathrm{Fe}^{3+}$ are indicated in blue and red colours, respectively. Diamonds denote measured spectrum, and black curve represents summed fitted spectra

error of $1 \%$ of the method. However, only minor changes in $\mathrm{Fe}^{3+} / \mathrm{Fe}_{\text {tot }}$ can be expected, as the $\mathrm{Fe}$ content is considerably higher than the change in $\mathrm{OH}$ content in terms of ions per formula unit for the studied samples.

\section{Pre-eruptive water content}

We estimated the water content of magma in equilibrium with clinopyroxene cores using the $\mathrm{H}$ values obtained after the rehydration experiments and based on the calibrations of Libowitzky and Rossman (1997) by using the DHcpx/melt partition coefficient of O'Leary et al. (2010). The resulting water content ranges between 0.71 and $1.20 \mathrm{wt} \%$ (average $1.0 \mathrm{wt} \%$ ) (Table 4). No significant variation was observed for samples collected from different stratigraphic positions. The value provided by the $1718 \mathrm{cpx}$ megacryst from the 1718 eruption pyroclastic fallout has a value of $1.17 \mathrm{wt} \%$, in accordance with the range obtained from the pyroxenes in lava samples.

Turner et al. (2017) measured a magma water content of $1.1 \mathrm{wt} \%$ from two clinopyroxenes from Pico cumulitic lavas. They also measured zoned millimetric crystals in which the rim had a higher water content (235 ppm) than the core (40 ppm), an enrichment that correlates uniquely with the $\mathrm{Al}$ and $\mathrm{Fe}$ substitutions in the mineral. In fact, after a rehydration annealing experiment at $900{ }^{\circ} \mathrm{C}$ and $1.0 \mathrm{GPa}$ Turner et al. (2017) observed that the re-hydrated clinopyroxene rim retained a $\mathrm{H}$ content of $187 \mathrm{ppm}$, comparable with the values of their untreated clinopyroxene rims suggesting that these were the maximum values of $\mathrm{H}$ solubility for Pico clinopyroxenes.

The pre-eruptive water content obtained by clinopyroxene well compare to that obtained by olivine-hosted melt inclusions from the nearby Pico fissure zone $(<0.8$ to $2.0 \mathrm{wt} \%$ $\mathrm{H}_{2} \mathrm{O}$; Métrich et al. 2014), whose large variability is related to up to $40 \% \mathrm{H}$ diffusion from the inclusions (Danyushevsky et al. 2000).

In Pico the magma ascent path at the fissure zone and the central volcano are different. Below the central volcano increased volumes of magma ponded for long time at the Moho Transition Zone (MTZ) at $\sim 18 \mathrm{~km}$ forming

Table 4 Pre-eruptive magma water content expressed in weight percent calculated for each sample according to O'Leary al. (2010) and using the Libowitzky and Rossman (1997)'s calibrations

\begin{tabular}{ll}
\hline & $\begin{array}{l}\mathrm{H}_{2} \mathrm{O} \text { in } \\
\text { melt wt\% }\end{array}$ \\
\hline 1718cpx & 1.17 \\
Pic22cpx & 1.00 \\
Pic64cpx & 1.14 \\
Pic43cpx & 0.83 \\
Pic32cpx & 1.08 \\
Pic61cpx & 1.19 \\
Pic59cpx & 0.71 \\
\hline
\end{tabular}


voluminous crystal mushes. Fractional crystallization or the accumulation of mafic phases originated the magmas typically erupted by the volcano lateral vents at lower altitudes, while fractional crystallization at a depth of $5.6-6.8 \mathrm{~km}$ originated the magma erupted by the volcano summit (Zanon and Frezzotti 2013; Zanon et al. 2020). The magma erupted by the fissure system is instead affected by a short period of magma ponding at the MTZ, with no crystal mush formation and very limited processes of fractional crystallisation (Métrich et al. 2014; Zanon and Frezzotti 2013).

In clinopyroxenes $\mathrm{Mg} \#[100 \mathrm{Mg} /(\mathrm{Mg}+\mathrm{Fe})]$ and $\mathrm{Ca} \#$ $[100 \mathrm{Ca} /(\mathrm{Ca}+\mathrm{Mg})]$ differentiation indexes are negatively correlated during fractional crystallization processes and $\mathrm{H}$ content decreases by Ca-number increase (Bell et al. 2004). Pico clinopyroxenes have a very limited variation of both $\mathrm{Mg \#} \mathrm{(from} 74$ to 81) and Ca\# (from 48 to 50), as well as a relatively similar composition of major elements and water content (93-182 ppm). Moreover, even if the trace elements enrichment of 1718cpx, Pic22cpx and Pic64cpx seems to be related to heterogeneities in the magmatic system (parental magma primary differences, crystallization related zonations, or different degree of interaction with metasomatic agents), all the studied Pico cpx resulted in equilibrium with the average basaltic composition we selected as a proxy for the erupted primitive magmas at Azores volcanoes.

\section{Clinopyroxene thermobarometry}

Figure 7 reports the unit cell vs. M1 volumes. In detail we observed that 1718cpx, Pic22cpx and Pic64cpx pyroxenes have the largest unit cell and M1 volumes and crystallised at shallower conditions than Pic61cpx, Pic43cpx, Pic32cpx and Pic59cpx pyroxenes. If we compare geobarometric data of Pico cpx with similar literature data (Dal Negro et al. 1989; Nazzareni et al. 1998, 2001, 2003, 2020) a

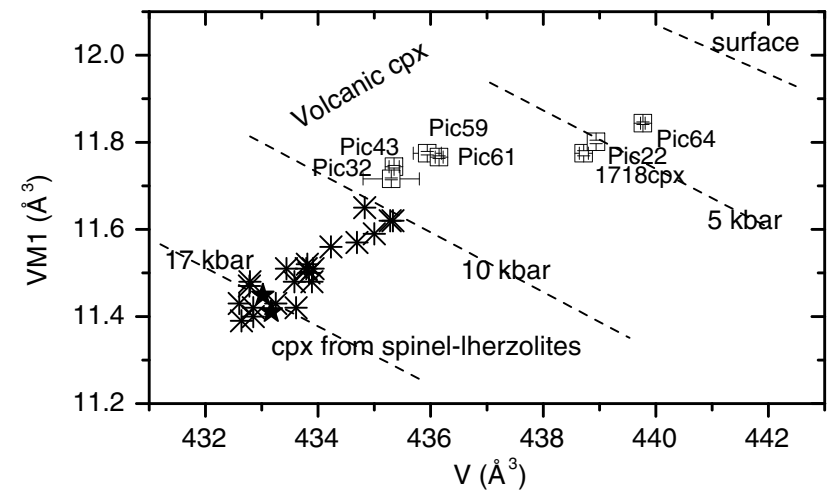

Fig. 7 Volume of M1 octahedron plotted against the cell volume. Symbols: full squares Pico Volcano cpx; asterisks: cpx from spinellherzolite rocks (Dal Negro et al. 1982); star: cpx from pyroxenite nodules included in Oahu alkaline lava (Hawaii) (Nazzareni et al. 2003) crystallization pressure of around 8-9 kbar $(\sim 28-31 \mathrm{~km}$ depth) can be inferred for the deepest samples and around 4-5 kbar ( 15-19 km depth) for the shallowest.

Pressure values obtained on the basis of structural geometries of the analysed clinopyroxenes have been compared with independent geobarometers based on the chemistry of crystalliquid pairs (Putirka et al. 1996; Putirka 2008), reported in Fig. 8a and Table S5. Pressure estimations reported in Fig. 8a highlight a range of most probable pressure storages (based on interquartile ranges) between 4 and $9 \mathrm{kbar}$, in agreement with the results showed in Fig. 7 and based on the unit cell vs. M1 volumes distributions. Also, Fig. 8 do not show significant differences between the pressure storage of Pico magmas and those concerning the all Azores Archipelago. Temperature estimates based on Eq. 1 (Putirka et al. 1996), 33 (Putirka 2008) and 34 (Putirka 2008) define a most probable crystallization interval for Pico clinopyroxenes from $\sim 1180$ to $\sim 1250^{\circ} \mathrm{C}$.

Petrological models suggest that Pico magmas derived from mantle melting in the garnet stability field ( $3 \mathrm{GPa}$, $98 \mathrm{~km}$ ), then during ascent mafic phases crystallized between 16-8 kbar (53-28 km depth) before ponding at the MTZ around $18 \mathrm{~km}(\sim 5 \mathrm{kbar})$ where fractional crystallization or/ and crystal accumulation occurred (Métrich et al. 2014; Zanon et al. 2020; Beier et al. 2012). An ultimate ponding step occurs in a small magma storage system located only beneath the central volcano at 5.6-6.8 km depth where fractional crystallization generates the plagioclase bearing magmas erupted during the last $10 \mathrm{ka}$ by the summit crater (Zanon et al. 2020).

Combining this model with the cpx geobarometric calculations reported above we can infer that most of our pyroxene cores have crystallised in the lithospheric mantle at about 8-9 kbar whereas 1718cpx, Pic22cpx and Pic64cpx crystallised at the ponding system in the oceanic crust at around 12-18 km (4-5 kbar) (Figs. 7, 8).

Moreover, the observed crystallisation pressure distribution correlates to the different amount of hydrogen loss: high pressure clinopyroxenes loss all their pre-eruptive water content, clinopyroxenes which crystallized at crustal depth retained instead some pre-eruptive water content. We may hypothesize that a longer ascent to surface and a prolonged ponding at the MTZ enhanced the $\mathrm{H}$ loss by iron redox processes in the high-pressure pyroxene respect to the lowpressure pyroxene.

The different lava cooling rates, as expressed by the $\mathrm{Tc}$ calculated for Pico pyroxene $\left(T_{\mathrm{c}}=554-949{ }^{\circ} \mathrm{C} \pm 20{ }^{\circ} \mathrm{C}\right)$, further enhanced the $\mathrm{H}$ loss by iron redox processes after the eruptions. This second dehydration step possibly added to the pre-eruptive $\mathrm{H}$ loss leaving as a consequence lowpressure pyroxene (Pic64cpx, 1718cpx, Pic22cpx) to retain weak $\mathrm{OH}$ bands in the FTIR spectra (as measured before annealing experiments). 
Fig. 8 Comparison plot for temperature (a) and pressure (b) for Pico cpx and the all dataset for Azores cpx from GEOROC. Values are calculated from different calibrations, including the equations T1 (Putirka et al. 1996), 33 (Putirka 2008), and 34 (Putirka 2008) for the temperature and the equations $\mathrm{P} 1$ (Putirka et al. 1996), 30 (Putirka 2008), 32a (Putirka 2008) an 32b (Putirka 2008) for the pressure. See text for explanation
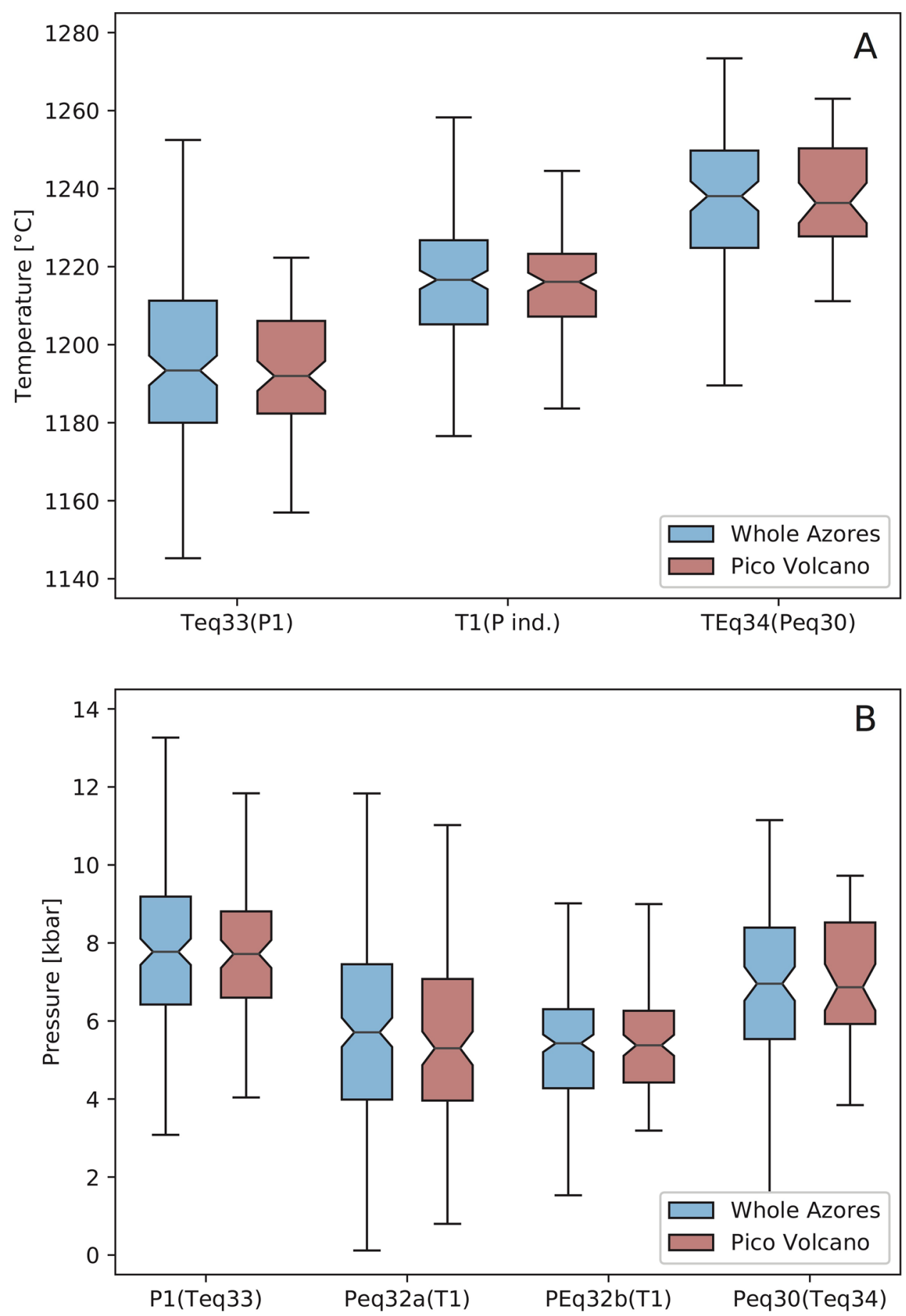

\section{Pico parental magmatic water content in the Azores Archipelago context and OIB system}

Water contents of Azores magmas have been estimated by melt inclusions hosted in primitive olivine (Métrich et al. 2014; Turner et al. 2017) and from clinopyroxene (this work and Turner et al. 2017). Some difference arises in the magma $\mathrm{H}_{2} \mathrm{O}$ content calculated from these two methods that when combined extend the estimated magma water content in Pico.

The work by Turner et al. (2017) aimed at providing a general view at the scale of the archipelago, by comparing a few analyses of $\mathrm{H}_{2} \mathrm{O}$ dissolved in melt inclusions in olivine and the water content obtained by the analysis in clinopyroxenes. The pre-eruptive magma water content for the Azores estimated by Turner et al. (2017) from clinopyroxene is very low for Corvo (0.4-1.2 wt \%), Flores (0.3-0.4 wt \%) and Faial 
Fig. 9 Schematic model of the Azores volcanic system along a W-E direction modified from Beier et al. (2008). A: Crystallisation location of high pressure Pico cpx; B crystallisation location of low pressure Pico cpx; $\mathrm{C}$ shallower magma ponding. Pre-eruptive magma water content is reported: data for Faial and Sao Miguel are from Turner et al. (2017). Star symbol is the estimated magma water content at cpx crystallisation pressure of Pico Volcano

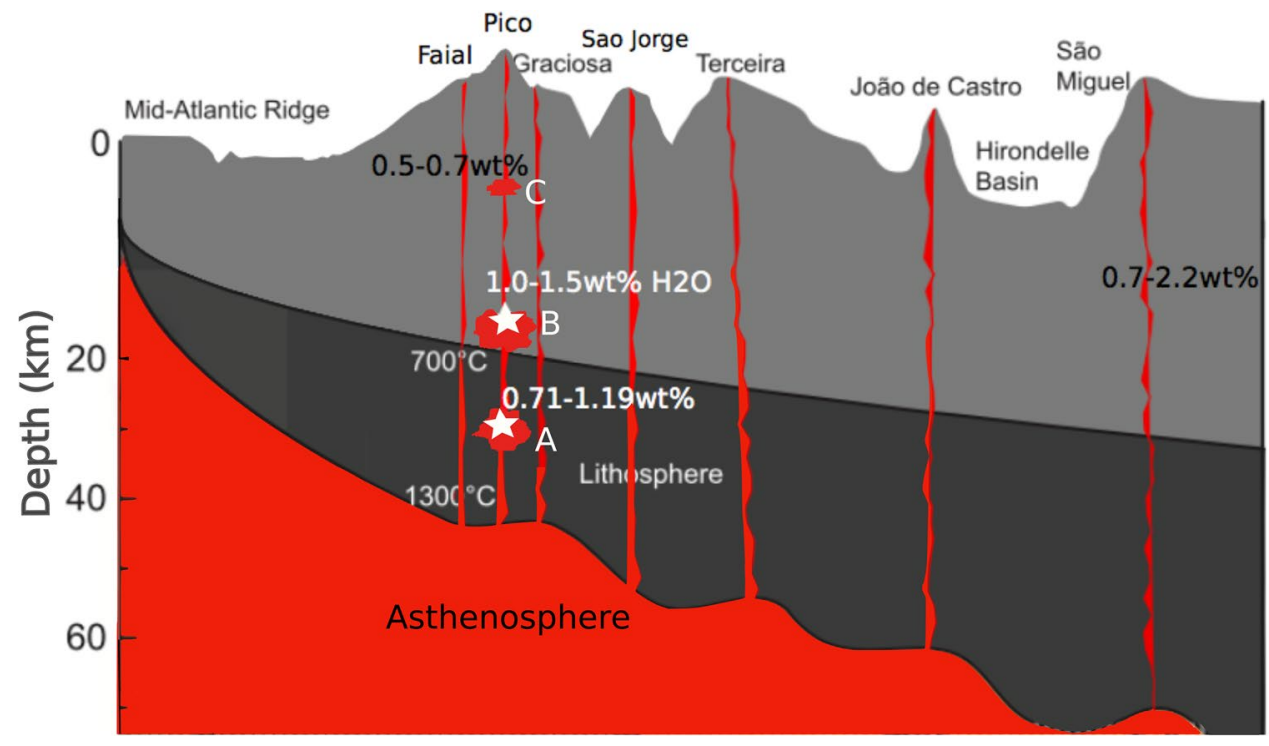

(0.5-0.7wt\%) and higher in São Miguel (0.7-2.2 wt\%) and Pico (1.0-1.3 wt \%).

Nevertheless, except for Pico, these are minimum values because no re-hydration experiments were carried out by Turner et al. (2017) to test whether H loss occurred as we observed in Pico.

These data define a general trend for the minimum water content in the Azores magmas nevertheless the evolution trend in the single islands is still unknown. Our data agree with the values of Turner et al. (2017), further suggesting that in Pico a limited variation in the magma water content occurred during the evolution of the Pico Volcano eruptions since $40 \mathrm{ka}$ (Fig. 9).

At the scale of the archipelago, the magma water content overlap the values reported for OIB magma from different island systems (Weis et al. 2015 and reference therein): Hawaii 0.7-1.4 wt\%, Revilagigedo Islands 0.5-1.2 wt\%, Canary Islands 0.5-1.5 wt\%. Moreover, we estimated a water content for Pico magma at lithospheric mantle depths similar to that obtained for Canary Islands magmas (0.7-1.5 wt \%, Weis et al. 2015) at similar conditions.

The mantle reservoir for OIB is considered to be water rich and consequently the OIB magmas water content is generally higher than typical values of MAR basalts (Hirschmann 2006; Dixon et al. 2002). In particular, MAR basalts in the Azores region have an average water content of $0.46 \mathrm{wt} \%$ (min 0.21-max $1.22 \mathrm{wt} \% \mathrm{H}_{2} \mathrm{O}$; Dixon et al. 2002) lower than the values measured in the Azores magmas (this study, Métrich et al. 2014; Turner et al. 2017).

\section{Conclusions}

We estimated a pre-eruptive maximum water content (as recorded by clinopyroxene) of $1.20 \mathrm{wt} \%$ for the recent magmas erupted by Pico Volcano, in agreement with the values reported in literature for the Azorean OIB mafic magmas (minimum average value $0.98 \mathrm{wt} \%$ Turner et al. 2017) and higher than the associated MORB. The similar major and trace chemistry, water content and $\mathrm{Fe}^{3+} / \mathrm{Fe}_{\text {tot }}$ ratio, suggested similar condition of oxygen fugacity, water content and fractional crystallisation of the parental primitive magma from which clinopyroxene cores crystallised over the Pico Volcano evolution from $40 \mathrm{ka}$ to historical times. The preeruptive magma water content estimated by clinopyroxene does not vary significantly in the central volcano being in the range 0.71-1.20 (average 1.0) wt\%. Moreover Pico Volcano pyroxenes recorded both a crystallisation in the lithospheric mantle (ca. 24-27 km) and at the oceanic crust/ mantle boundary (ca. 12-15 km) (Fig. 9), thus the estimated water content may be considered representative of the early phase of evolution of the parental magmas at lithospheric mantle depth.

Acknowledgements We thank Teresa Ubide and an anonymous referee for their constructive reviews. Editor Gordon Moore is greatly acknowledged for handling the manuscript. This study was partially funded by Fundação para a Ciência e Tecnologia, Portugal (MARES Project PTDC/GEO-FIQ/1088/2014). The Parque Natural do Pico is acknowledged for providing free access to the summit of Pico volcano during field surveys. A. Risplendente and S. Poli of the Department of Earth Sciences "Ardito Desio" University of Milan (Italy) are gratefully acknowledged for their assistance with microprobe analyses.

Funding Open access funding provided by Università degli Studi di Perugia within the CRUI-CARE Agreement. 
Open Access This article is licensed under a Creative Commons Attribution 4.0 International License, which permits use, sharing, adaptation, distribution and reproduction in any medium or format, as long as you give appropriate credit to the original author(s) and the source, provide a link to the Creative Commons licence, and indicate if changes were made. The images or other third party material in this article are included in the article's Creative Commons licence, unless indicated otherwise in a credit line to the material. If material is not included in the article's Creative Commons licence and your intended use is not permitted by statutory regulation or exceeds the permitted use, you will need to obtain permission directly from the copyright holder. To view a copy of this licence, visit http://creativecommons.org/licenses/by/4.0/.

\section{References}

Asimow PD, Dixon JE, Langmuir CH (2004) A hydrous melting and fractionation model for mid-ocean ridge basalts: application to the Mid-Atlantic Ridge near the Azores. Geochem Geophys Geosyst. https://doi.org/10.1029/2003GC000568

Beier C, Haase KM, Abouchami W, Krienitz M-S, Hauff F (2008) Magma genesis by rifting of oceanic lithosphere above anomalous mantle: Terceira Rift Azores. Geochem Geophys Geosyst 9:Q12013. https://doi.org/10.1029/2008GC002112

Beier C, Haase KM, Turner SP (2012) Conditions of melting beneath the Azores. Lithos 144-145:1-11

Bell DR, Rossman GR, Moore RO (2004) Abundance and partitioning of $\mathrm{OH}$ in a high-pressure magmatic system: megacrysts from the Monastery kimberlite, South Africa. J Petrol 45:1-26

Bindi L, Conticelli S, Menchetti S (1999) Crystal chemistry of clinopyroxene from alkaline undersaturated rocks of the Monte Vulture Volcano, Italy. Lithos 46:259-274

Bourdon B, Turner SP, Ribe NM (2005) Partial melting and upwelling rates beneath the Azores from a U-series isotope perspective. Earth Planet Sci Lett 239:42-56

Cannat M, Briais A, Deplus C, Escartin J, Georgen J, Lin J et al (1999) Mid-Atlantic Ridge-Azores hotspot interactions: along axis migration of a hot-spot derived event of enhanced magmatism 10-4 Ma ago. EPSL 173:257-269

Cherniak DJ, Dimanov A (2010) Diffusion in pyroxene, mica and amphibole. In: Zhang Y, Cherniak DJ (eds) Diffusion in minerals and melts, vol 72. Reviews in Mineralogy and Geochemistry, Mineralogical Society of America and Geochemical Society, Washington, pp 641-690

Costa ACG, Marques FO, Hildenbrand A, Sibrant ALR, Catita CMS (2014) Large-scale catastrophic flank collapses in a steep volcanic ridge: the Pico-Faial Ridge, Azores Triple Junction. J Volcanol Geoth Res 272:111-125

Courtillot V, Davaille A, Besse J, Stock J (2003) Three distinct types of hotspots in the Earth's mantle. EPSL 205:295-308

Dal Negro A, Carbonin S, Molin GM, Cundari A, Piccirillo EM (1982) Intracrystalline cation distribution in natural clinopyroxenes of tholeiitic, transitional, and alkaline basaltic rocks. In: Saxena SK (ed) Advances in physical geochemistry, vol 2. Springer-Verlag, Berlin, pp 117-150

Dal Negro A, Molin GM, Salviulo G, Secco L, Cundari A, Piccirillo EM (1989) Crystal chemistry of clinopyroxenes and its petrogenetic significance: a new approach. Int Lithosphere Prog Mid Term Conf 80:271-295

Danyushevsky LV, Della-Pasqua FN, Sokolov S (2000) Re-equilibration of melt inclusions trapped by magnesian olivine phenocrysts from subduction-related magmas: petrological implications. Contrib Mineral Petrol 138:68-83
Dixon JE, Leist L, Langmuir CH, Schilling JG (2002) Recycled dehydrated lithosphere observed in plume-influenced mid-ocean ridge basalt. Nature 420:385-389

Elliott T, Blichert-Toft J, Heumann A, Koetsier G, Forjaz V (2007) The origin on the enriched mantle beneath Sao Miguel, Azores. Geochim Cosmochim Acta 71:219-240

Ferriss E, Plank T, Walker D (2016) Site-specific hydrogen diffusion rates during clinopyroxene dehydration. Contrib Mineral Petrol 171:55

Franca ZTM, Tassinari CCG, Cruz JV, Aparicio AY, Arana V, Rodrigues $\mathrm{BN}$ (2006) Petrology, geochemistry and $\mathrm{Sr}-\mathrm{Nd}-\mathrm{Pb}$ isotopes of the volcanic rocks from Pico Island-Azores (Portugal). J Volcanol Geotherm Res 156:71-89

Hammer J, Jacob S, Welsch B et al (2016) Clinopyroxene in postshield Haleakala ankaramite: 1. Efficacy of thermobarometry. Contrib Mineral Petrol 171(7)

Hirschmann M (2006) Water, melting, and the deep earth $\mathrm{H}_{2} \mathrm{O}$ cycle. Ann Rev Earth Planet Sci 34:629-653

Jernberg P, Sundqvist B (1983) A versatile Mössbauer analysis program. Uppsala University, Institute of Physics (UUIP1090)

Keppler H, Smyth JR (2006) Water in nominally anhydrous minerals. Reviews in mineralogy and geochemistry, vol 62. Mineralogical Society of America and Geochemical Society, Washington, pp 193-230

Larrea P, Wijbrans PR, Gale C, Ubide T, Lago M, Franza Z (2014) 40Ar/39Ar constraints on the temporal evolution of Graciosa Island, Azores (Portugal). Bull Volcanol 76:796

Larrea P, França Z, Widom E, Lago M (2018) Petrology of the Azores Islands. In: Kueppers U and Beier C (eds) Volcanoes of the Azores, Active Volcanoes of the World. pp 197-249

Libowitzky E, Rossman GR (1997) An IR absorption calibration for water in minerals. Am Mineral 82:1111-1115

Lloyd AS, Ferriss E, Ruprecht P, Hauri EK, Jicha BR, Plank T (2016) An assessment of clinopyroxene as a recorder of magmatic water and magma ascent rate. J Petrol 57:1865-1886

McDonough WF, Sun SS (1995) The Composition of the Earth. Chem Geol 120:223-253

Métrich N, Zanon V, Créon L, Hildenbrand A, Moreira M, Marques FO (2014) Is the "Azores hotspot" a wetspot? Insights from the geochemistry of the fluid and melt inclusions in olivines of Pico basalts. J Petrol 55(2):377-393

Mollo S, Blundy J, Scarlato P, De Cristofaro SP, Tecchiato V, Di Stefano F, Vetere F, Holtz F, Bachman O (2018) An integrated $\mathrm{P}-\mathrm{T}-\mathrm{H}_{2} \mathrm{O}$-lattice strain model to quantify the role of clinopyroxene fractionation on REE $+Y$ and HFSE patterns of mafic alkaline magmas: application to eruptions at Mt. Etna Earth Sci Rev 185:32-56

Montelli R, Nolet G, Dahlen FA, Masters G (2004) A catalogue of deep mantle plumes: New results from finite-frequency tomography. Geochem Geophys Geosyst. https://doi. org/10.1029/2006GC001248

Mosenfelder JL, Rossman GR (2013) Analysis of hydrogen and fluorine in pyroxenes: II. Clinopyroxene Am Mineral 98(5-6):1042-1054

Müller RD, Sdrolias M, Gaina C, Roest WR (2008) Age, spreading rates and spreading symmetry of the world's ocean crus. Geochem Geophys Geosyst. https://doi.org/10.1029/2007GC001743

Murri M, Camara F, Adam J, Domeneghetti MC, Alvaro M (2018) Intracrystalline "geothermometry" assessed on clino and orthopyroxene bearing synthetic rocks. Geochim Cosmochim Acta 227:133-142

Nazzareni S, Molin G, Peccerillo A, Zanazzi PF (1998) Structural and chemical variations in clinopyroxenes from the Island of Alicudi (Aeolian arc) and their implications for conditions of crystallization. Eur J Mineral 10(2):291-300

Nazzareni S, Molin G, Peccerillo A, Zanazzi PF (2001) Volcanological implications of crystal-chemical variations in clinopyroxenes from 
the Aeolian Arc, Southern Tyrrhenian Sea (Italy). Bull Volcanol 63:73-82

Nazzareni S, Busà T, Cristofolini R (2003) Magmatic crystallisation of $\mathrm{Cr}-\mathrm{Al}$ diopside and $\mathrm{Al}-\mathrm{Fe} 3+$ diopside from the ancient alkaline basalts (Mt Etna, Sicily). Eur J Mineral 15(1):81-93

Nazzareni S, Skogby H, Zanazzi PF (2011) Hydrogen content in clinopyroxene phenocrysts from Salina mafic lavas (Aeolian arc, Italy). Contrib Mineral Petrol 162(2):275-288

Nazzareni S, Rossi S, Petrelli M, Caricchi L (2020) Architecture of the magmatic system in the Main Ethiopian Rift. In: Vedere F (ed) Dynamic Magma Evolution, Geophysical Monograph 254, American Geophysical Union, pp 133-151

Nimis P (1999) Clinopyroxene geobarometry of magmatic rocks. Part 2. Structural geobarometers for basic to acid, tholeiitic and mildly alkaline magmatic system. Contrib Mineral Petrol 135:62-74

Nimis P, Ulmer P (1998) Clinopyroxene geobarometry of magmatic rocks. 1. An expanded structural geobarometer for anhydrous and hydrous, basic and ultrabasic systems. Contrib Mineral Petrol 133:314-327

Nunes JC, Cruz JV, França Z, Sigvaldason G, Carvalho MR, Garvin J, Alves JL (1999) Production rates and ages of Pico stratovolcano (Azores Islands): an estimation from historical eruptions data. In: Garcia-Garcia JMG, Romacho MDR (eds) Proceedings of "1a Assembleia Luso-Espanhola de Geodesia e Geofisica", Almeria, Spain. Universidad de Almeria and Instituto Geográ fico Nacional. Electronic Version (ISBN: 84-95172-10-0), p 6

O'Leary JA, Gaetani GA, Hauri EH (2010) The effect of tetrahedral Al on the partitioning of water between clinopyroxene and silicate melt. Earth Planet Sci Lett 297:111-120

Paton C, Hellstrom J, Paul B, Woodhead J, Hergt J (2011) Iolite: freeware for the visualisation and processing of mass spectrometric data. J Anal Atom Spect 26:2508-2518

Pearce JGN, Perkins WT, Westgate JA, Gorton MP, Jackson SE, Neal CR, Chenery SP (1997) A compilation of new and published major and trace element data for NIST SRM 610 and NIST SRM 612 glass reference materials. Geostand Newsl 21:115-144

Perugini D, Busà T, Poli G, Nazzareni S (2003) The role of chaotic dynamics and flow fields in the development of disequilibrium textures in volcanic rocks. J Petrol 44(4):733-756

Peslier AH, Luhr J, Post JE (2002) Low water contents in pyroxenes from spinel-peridotites of the oxidized sub-arc mantle wedge. Earth Planet Sci Lett 201:69-86

Petrelli M, Morgavi D, Vetere F, Perugini D (2016a) Elemental imaging and petro-volcanological applications of an improved Laser Ablation Inductively Coupled Quadrupole Plasma Mass Spectrometry. Per Mineral 85(1):25-39

Petrelli M, Morgavi D, Vetere F, Perugini D (2016b) High spatial resolution trace element determination of geological samples by laser ablation quadrupole plasma mass spectrometry: implications for glass analysis in volcanic products. Geosci J 20(6):851-863

Prytulak J, Elliott T (2009) Determining melt productivity of mantle sources from 238U-230Th and 235U-231Pa disequilibria; an example from Pico Island, Azores. Geochim Cosmochim Acta 73:2103-2122

Putirka KD (2008) Thermometers and barometers for volcanic systems. In: Putirka K, Tepley F (eds) Minerals, inclusions and volcanic processes. Reviews in Mineralogy and Geochemistry. Mineralogical Society of America, New York, pp 61-120

Putirka KD, Johnson M, Kinzler R, Longhi J, Walker D (1996) Thermobarometry of mafic igneous rocks based on clinopyroxeneliquid equilibria, 0-30 kbar
Putirka KD, Ryerson FJ, Mikaelian H (2003) New igneous thermobarometers for mafic and evolved lava compositions, based on clinopyroxene + liquid equilibria. Am Mineral 88:1542-1554

Schilling JG (1975) Azores mantle blob: rare-earth evidence. EPSL 25:103-115

Sheldrick GM (2008) A short history of SHELX. Acta Cryst A64:112-122

Skogby H (2006) Water in natural mantle minerals I: pyroxenes. In: Keppler H, Smyth JR (eds) Water in nominally anhydrous minerals. Reviews in Mineralogy and Geochemistry. Mineralogical Society of America and Geochemical Society, Washington, pp $155-168$

Turner M, Turner S, Mironov N, Portnyagin M, Hoernle K (2017) Can magmatic water contents be estimated from clinopyroxene phenocrysts in some lavas? A case study with implications for the origin of the Azores Islands. Chem Geol 466:436-445

Wade JA, Plank T, Hauri EH, Kelley KA, Roggensack K, Zimmer M (2008) Prediction of magmatic water contents via measurement of $\mathrm{H}_{2} \mathrm{O}$ in clinopyroxene phenocrysts. Geology 36:799-802

Wallace PJ (2005) Volatiles in subduction zone magmas: concentrations and fluxes based on melt inclusion and volcanic gas data. J Volcanol Geotherm Res 140:217-240

Waters CL, Day JMD, Watanabe S, Sayit K, Zanon V, Olson KM, Hanan BB, Widom E (2019) Sulfide mantle source heterogeneity recorded in basaltic lavas from the Azores. Geochim Cosmochim Acta 268:422-445. https://doi.org/10.1016/j.gca.2019.10.012

Weis FA, Skogby H, Troll VR, Deegan FM, Dahren B (2015) Magmatic water contents determined through clinopyroxene: examples from the western Canary Islands Spain. Geochem Geophys Geosyst. https://doi.org/10.1002/2015GC005800

Weis FA, Skogby H, Stalder R (2016) Experimental hydration of natural volcanic clinopyroxene phenocrysts under hydrothermal pressures (0.5-3 kbar). Am Mineral 101(10):2233-2247

Weis FA, Bellucci JJ, Skogby H, Stalder R, Nemchin AA, Whitehouse MJ (2017) Water content in the Martian mantle: a Nakhla perspective. Geochim Cosmochim Acta 212:84-98

Wilson SA (1997) The collection, preparation, and testing of USGS reference material BCR-2, 557 Columbia River, Basalt. United States Geological Survey, Open-File Rep, p 98

Zanon V (2015) The magmatism of the Azores Islands. In: Gaspar JL, Guest JE, Duncan AM, Barriga FJAS, Chester DK (eds) Volcanic Geology of São Miguel Island (Azores Archipelago). The Geological Society of London, Memoirs, pp 51-64

Zanon V, Frezzotti ML (2013) Magma storage and ascent conditions beneath Pico and Faial islands (Azores Islands). A study on fluid inclusions. Geochem Geophys Geosyst 14(9):3494-3514

Zanon V, Pimentel A, Auxerre M, Marchini G, Stuart FM (2020) Unravelling the magma feeding system of a young basaltic oceanic volcano. Lithos 352:105325

Zhang Y-S, Tanimoto T (1992) Ridges, hotspots and their interaction as observed in seismic velocity maps. Nature $355: 45-49$

Publisher's Note Springer Nature remains neutral with regard to jurisdictional claims in published maps and institutional affiliations. 